\title{
Development of Voltage-Dependent Calcium, Sodium, and Potassium Currents in Xenopus Spinal Neurons
}

\author{
Diane K. O'Dowd, a Angeles B. Ribera, and Nicholas C. Spitzer \\ Department of Biology, University of California, San Diego, La Jolla, California 92093
}

\begin{abstract}
Action potentials of embryonic nerve and muscle celis often have a different ionic dependence and longer duration than those of mature cells. The action potential of spinal cord neurons from Xenopus laevis exhibits a prominent calcium component at early stages of development that diminishes with age as the impulse becomes principally sodium dependent. Whole-cell voltage-clamp analysis has been undertaken to characterize the changes in membrane currents during development of these neurons in culture. Four voltage-dependent currents of cells were identified and examined during the first day in vitro, when most of the change in the action potential occurs.

There are no changes in the peak density of the calcium current $\left(I_{\mathrm{Ca}}\right)$, its voltage dependence, or time to half-maximal activation; a small increase in inactivation is apparent. The major change in sodium current $\left(I_{\mathrm{Na}}\right)$ is a 2-fold increase in its density. In addition, more subtle changes in the kinetics of the macroscopic sodium current were noted. The peak density of voltage-dependent potassium current $\left(I_{\mathrm{kv}}\right)$ increases 3-fold, and this current becomes activated almost twice as fast. No changes were noted in the extent of its inactivation. The calcium-dependent potassium current $\left(I_{\mathrm{kc}}\right)$ consists of an inactivating and a sustained component. The former increases 2-fold in peak current density, and the latter increases similarly at less depolarized voltages. The changes in these currents contribute to the decrease in duration and the change in ionic dependence of the impulse.
\end{abstract}

The ionic dependence of the action potential of excitable cells at early developmental stages is often different from that of the mature cells (Takahashi et al., 1971; Sperelakis and Shigenobu, 1972; Kano, 1975; Kidokoro, 1975; Baccaglini and Spitzer, 1977; Salkoff and Wyman, 1983; for review, see Spitzer, 1983). The action potential of spinal cord neurons from Xenopus laevis, both in vivo and in culture, is initially long in duration and primarily dependent on an inward calcium current. During development the contribution of sodium current to the action potential increases, while the calcium component decreases; the mature action potential is primarily sodium dependent (Spitzer

\footnotetext{
Received May 15, 1987; revised Aug. 10, 1987; accepted Aug. 13, 1987.

We thank Rosario De Baca and Forrest Gompf for expert technical assistance. We are grateful to R. W. Aldrich, K. Dunlap, G. L. Harris, L. P. Henderson, M. A. Smith, and J. H. Steinbach for their comments on earlier versions of the manuscript. This work was supported by an NSF predoctoral fellowship to D.K.O., an NIH postdoctoral fellowship to A.B.R., and NIH NS15918 to N.C.S.

Correspondence should be addressed to Nicholas $C$. Spitzer at the above address

${ }^{a}$ Present address: Department of Neurobiology, Stanford University School of Medicine, Stanford, CA 94305.

Copyright $(C) 1988$ Society for Neuroscience $0270-6474 / 88 / 030792-14 \$ 02.00 / 0$
}

and Lamborghini, 1976; Baccaglini and Spitzer, 1977). A similar developmental change in the ionic dependence of the action potential has been observed in a number of other neuronal preparations (Baccaglini, 1978; Matsuda et al., 1978; Miyake, 1978; Fukuda and Kameyama, 1979; Meiri et al., 1981; Ahmed et al., 1983; Mori-Okamoto et al., 1983).

Many previous studies of the development of electrical excitability in neurons have focused on the action potential. Ion substitutions and addition of channel blocking agents were used to characterize the impulse at different developmental stages with respect to the ions necessary for its generation. From these studies it seemed possible that developmental changes in the inward currents of the ccll could account for the maturation of the action potential. However, voltage measurements during which the membrane resistance changes with time do not allow direct examination of the ionic currents involved in its generation. Developmental changes in the amplitude or activation kinetics of the outward currents that contribute to repolarization of the action potential may be important (Barish, 1986). A description of developing inward and outward currents will lead to an understanding of the molecular mechanisms by which this program of early differentiation is elaborated.

In this paper, the whole-cell voltage-clamp technique (Hamill et al., 1981) has been used to identify and characterize the inward and outward currents activated at the membrane voltages achieved during an action potential. Xenopus spinal neurons developing in culture were examined over a period of approximately $24 \mathrm{hr}$ during which most of the change in ionic dependence and duration of the impulse occurs. Calcium, sodium, and potassium currents, recorded primarily from the cell body, are present at all times examined. The peak current density, voltage dependence, and activation kinetics of the calcium current $\left(I_{\mathrm{Ca}}\right)$ are constant, while there is a modest increase in calcium current inactivation. A 2 -fold increase in sodium current $\left(I_{\mathrm{Na}}\right)$ density and subtle changes in kinetics are observed. A voltagedependent potassium current $\left(I_{\mathrm{KV}}\right)$ increases in density and activates more rapidly. The density of calcium-dependent potassium currents $\left(I_{K_{c}}\right)$ increases as well. These changes contribute to the shortened duration and loss of the calcium component of the action potential that occurs over the same time period. Preliminary accounts of these findings have appeared (O'Dowd, 1983b, 1985; Ribera et al., 1986).

\section{Materials and Methods}

Cultures. Embryos of $X$. laevis were obtained by standard breeding procedures and staged by the criteria of Nieuwkoop and Faber (1956). Dissociated cell cultures were prepared by procedures modified from those of Spitzer and Lamborghini (1976) and Blair (1983). Briefly, posterior neural plates were dissected from stage 15 (neural plate) embryos 
in modified Steinberg's solution and dissociated in a divalent cationfree saline containing EDTA (in mM: $\mathrm{NaCl}, 58.2 ; \mathrm{KCl}, 0.7$; EDTA, 0.4 Tris-base, $4.6, \mathrm{pH} \mathrm{7.8)}$. Cells were plated into $60 \mathrm{~mm}$ Falcon tissue culture Petri dishes in $4 \mathrm{ml}$ of modified Steinberg's solution (in mM: $\mathrm{NaCl}, 58.2 ; \mathrm{KCl}, 0.7 ; \mathrm{Ca}\left(\mathrm{NO}_{3}\right)_{2}, 0.4 ; \mathrm{MgSO}_{4}, 1.3 ; \mathrm{CaCl}_{2} \cdot \mathrm{H}_{2} \mathrm{O}, 10 ; 20$ $\mu \mathrm{g} / \mathrm{ml}$ both penicillin and streptomycin; Tris-base, $4.6, \mathrm{pH} 7.8$ ). Cultures were maintained at $22^{\circ} \mathrm{C}$. Neurons were visualized with a $40 \times$ waterimmersion lens at a magnification of $500 \times$. Age of neurons is expressed as hours in culture. The designations "young," "intermediate," and "mature" refer to 6-9, 10-17, and 26-29 hr neurons.

Recording conditions. Sylgard-coated patch electrodes of 2-5 M $\Omega$ resistance when filled with internal solution were used to establish gigohm pipet-membrane seals. The residual capacitance associated with the electrode and patch was subtracted electronically prior to rupture of the patch. Currents were obtained using whole-cell voltage-clamp techniques (Hamill et al., 1981). The surface area of the cell was determined from the capacitative current elicited by a $10 \mathrm{mV}$ depolarizing voltage step following establishment of the whole-cell clamp. All recordings were performed at room temperature $\left(20-22^{\circ} \mathrm{C}\right)$.

Recording solutions. For recordings of inward currents, the pipet contained cesium to block outward potassium currents and EGTA to buffer the intracellular calcium concentration to a low level [internal solution (in mM): $\mathrm{CsCl}, 100 ; \mathrm{CaCl}_{2} \cdot \mathrm{H}_{2} \mathrm{O}, 0.64 ; \mathrm{EGTA}, 2$; and HEPES, 10 , $\mathrm{pH}$ adjusted to 7.4 with $\mathrm{CsOH}$ ]. The bathing solutions all contained TEACl to block potassium currents [external solution (in mM): $\mathrm{NaCl}, 40 ; \mathrm{CaCl}_{2}$. $2 \mathrm{H}_{2} \mathrm{O}, 10 ; \mathrm{KCl}, 3$; TEACl, 40; HEPES, 5, pH adjusted to 7.4 with $\mathrm{NaOH}$. With the exception of TEACl, the concentrations of these ions are the same as those used in previous analyses of development of the action potential (Blair, 1983; O'Dowd, 1983a). Steady perfusion of the culture dish allowed changes in composition of the external saline within $1 \mathrm{~min}$. In sodium-free solutions, Tris- $\mathrm{Cl}$ replaced $\mathrm{NaCl}$. In cobalt solutions, the calcium concentration was reduced to $5 \mathrm{~mm}$ and $10 \mathrm{~mm}$ $\mathrm{CoCl}_{2}$ was added. Experiments examining sodium current inactivation were performed in normal external saline to which $1 \mathrm{~mm} \mathrm{CdCl} \cdot 21 / 2$ $\mathrm{H}_{2} \mathrm{O}$ had been added. In control experiments, $1 \mathrm{~mm}$ cadmium was found to block inward calcium currents observed in the presence of $10 \mathrm{~mm}$ calcium ( 6 of 9 trials).

For the study of voltage-dependent, calcium-independent potassium currents, the pipet solution consisted of (in $\mathrm{mM}$ ) $\mathrm{KCl}, 100$; $\mathrm{KOH}, 26-$ 28; EGTA, 10; HEPES, 5, pH adjusted to 7.4 with $\mathrm{KOH}$. When calciumdependent potassium currents were to be recorded, the pipet was filled with a solution containing (in $\mathrm{mM}$ ) $\mathrm{KCl}, 90$; $\mathrm{KOH}, 3-5$; HEPES, 4.5 , pH 7.4; a calcium chelator was not added. This hypotonic solution aided in seal formation. Cells were continually superfused with saline [external solution (in $\mathrm{mM}$ ): $\mathrm{NaCl}, 80 ; \mathrm{KCl}, 3 ; \mathrm{MgCl}_{2}, 5 ; \mathrm{HEPES}, 5, \mathrm{pH}$ adjusted to 7.4 with $\mathrm{NaOH}$; TTX, $1 \mu \mathrm{g} / \mathrm{ml}$ ] to which the indicated divalent cation $(\mathrm{Ca}, \mathrm{Cd}$, or $\mathrm{Co}$ ) had been added. TTX was omitted from this solution when sodium currents were evaluated.

When examined in the same cell, sustained outward currents recorded in the presence of $0.5 \mathrm{~mm}$ cadmium were $22 \%$ larger than those recorded in $10 \mathrm{~mm}$ cobalt. The surface charge would be expected to be different under these 2 conditions. Another explanation is that $10 \mathrm{~mm}$ cobalt reduces voltage-dependent potassium current. However, when cobalt records were subtracted from those obtained in cadmium, an initial transient inward current was often observed, followed by a sustained outward current and inward tail currents. These observations are consistent with the possibility of persistent inward currents in low levels of cadmium, which are associated with activation of an outward current. Although this phenomenon was not examined further, it reveals that the magnitude of the outward current was slightly different under the 2 recording conditions.

Calcium current washout. The calcium currents in these as in other internally perfused cells wash out or run down with a variable time course (Byerly and Hagiwara, 1982; Fenwick et al., 1982). Therefore, all of the data presented were taken from cells in which the calcium currents were measured during the first minute after the whole-cell configuration was established. Records were taken until a decline in the peak current amplitude was recorded. It is possible that the selection of cells that showed no washout may have affected estimates of developmental changes in calcium currents. However, the measured value of calcium current density $\left(0.5 \mathrm{pA} / \mu \mathrm{m}^{2}\right)$ using this technique is comparable to that calculated on the basis of intracellular recordings $(0.3$ $\mathrm{pA} / \mu \mathrm{m}^{2}$; Baccaglini and Spitzer, 1977), where washout is not prevalent.

Data acquisition and analysis. A PDP $-11 / 23$ computer and a Cheshire Data interface board were used to generate voltage steps and to digitize and store current records. Neurons were voltage-clamped with a Dagan 8900 patch-clamp amplifier with a $1 \mathrm{G} \Omega$ headstage. For most experiments, cells were held at $-80 \mathrm{mV}$ and stepped to depolarizing command potentials at a rate of $1 \mathrm{~Hz}$; current responses were filtered with an 8 pole Bessel filter and sampled. Small leak currents persist when voltagedependent sodium, calcium, and potassium currents are suppressed. All current records were corrected for capacitative and leakage currents by subtracting a linearly scaled current elicited by a small $(10 \mathrm{mV})$ depolarizing voltage step, with the exception of those from experiments illustrated in Figures $8 C$ and $10 C$.

Inward current data were acquired between the months of June and December. Sodium currents were filtered at $5 \mathrm{kHz}$, and digitized at intervals of $100 \mu \mathrm{sec}$; they represent the average of $1-6$ trials. Calcium currents were filtered at $5 \mathrm{kHz}$ and sampled at 100 or $400 \mu \mathrm{sec}$ intervals. Outward currents recorded in the spring and summer were $80 \%$ larger than those recorded in the fall and winter. The basis of this observation is unknown. Pilot studies indicated that the relative increase in the amplitude of each current between 6 and $29 \mathrm{hr}$ in culture was the same for both time periods, however. Data were acquired between the months of March and Junc for $I_{\mathrm{Kv}}$, and between October and February for $I_{\mathrm{Kc}}$. Current responses were typically filtered at a frequency of 2.5 or $5 \mathrm{kHz}$ with a sampling interval of $200 \mu \mathrm{sec}$; in a few experiments (Fig. 10C), data were sampled at $1000 \mu \mathrm{sec}$ and filtered at $5 \mathrm{kIIz}$. Peak current amplitudes and times to peak or half-maximal were evaluated by computer programs.

Series resistance. For inward currents, the series resistance was determined from the peak of the capacitative transient, measured using a $10 \mathrm{kHz}$ band width and a sampling rate of $100 \mu \mathrm{sec}$ for a small number of cells. Based on these findings and those of Marty and Neher (1983), the calculations of series resistance error were routinely made by estimation of series resistance as twice the resistance of the open pipet. An electronic circuit on the patch-clamp amplifier was employed to compensate for a variable percentage of the series resistance in each cell. The remaining series resistance error for the maximum sodium and calcium currents from young cells was approximately $3 \mathrm{mV}$. However, the maximum sodium currents for older cells are generally of larger amplitude, and for these cells, the average residual series resistance error was estimated to be about $7 \mathrm{mV}$. Graphical presentations of data are uncorrected.

Series resistance compensation was similarly employed for outward currents, and in most cases residual errors were estimated to be only a few millivolts. In studies of $I_{\mathrm{Kv}}$ at late developmental stages, the bigger currents elicited by large depolarization introduced a greater error. The current-voltage relation was shown to be little affected, however; the difference in the current obtained in the presence and absence of compensation, evaluated in a small sample of cases, can be accounted for by a voltage shift of less than $5 \mathrm{mV}$. No correction has been applied to the $I-V$ relation. The presence and absence of series resistance compensation similarly had little impact on the voltage dependence of activation of this current, since compensation decreased the time to half maximal by $10 \%$ or less (within the SEM). In studies of $I_{\mathrm{Kc}}$, neither the inactivating nor the sustained components werc attributable to large series resistance errors, since they were present in young and mature cells when the estimated uncompensated error was only a few millivolts. However, the larger series resistance errors associaled with the measurement of total potassium current $\left(I_{\mathrm{KV}}\right.$ plus $\left.I_{\mathrm{Kc}}\right)$ made it difficult to routinely apply adequate compensation to older cells. Accordingly, compilations of developmental changes in the $I-V$ relations and the times to half-maximal current are not presented. Errors due to uncompensated series resistances at the higher voltages in older cells will result in underestimates of the developmental increases observed in both current amplitudes and activation rates.

\section{Results}

\section{Cell cultures}

Cultures prepared from the presumptive spinal cord region of neural plate stage embryos contain neurons, myocytes, and several other types of cells (Spitzer and Lamborghini, 1976; Willard, 1980). The population of neurons in these cultures, though heterogeneous, is primarily composed of cells with early birthdates which consist of Rohon-Beard cells, motoneurons, and interneurons (Spitzer and Lamborghini, 1976; Lamborghini, 

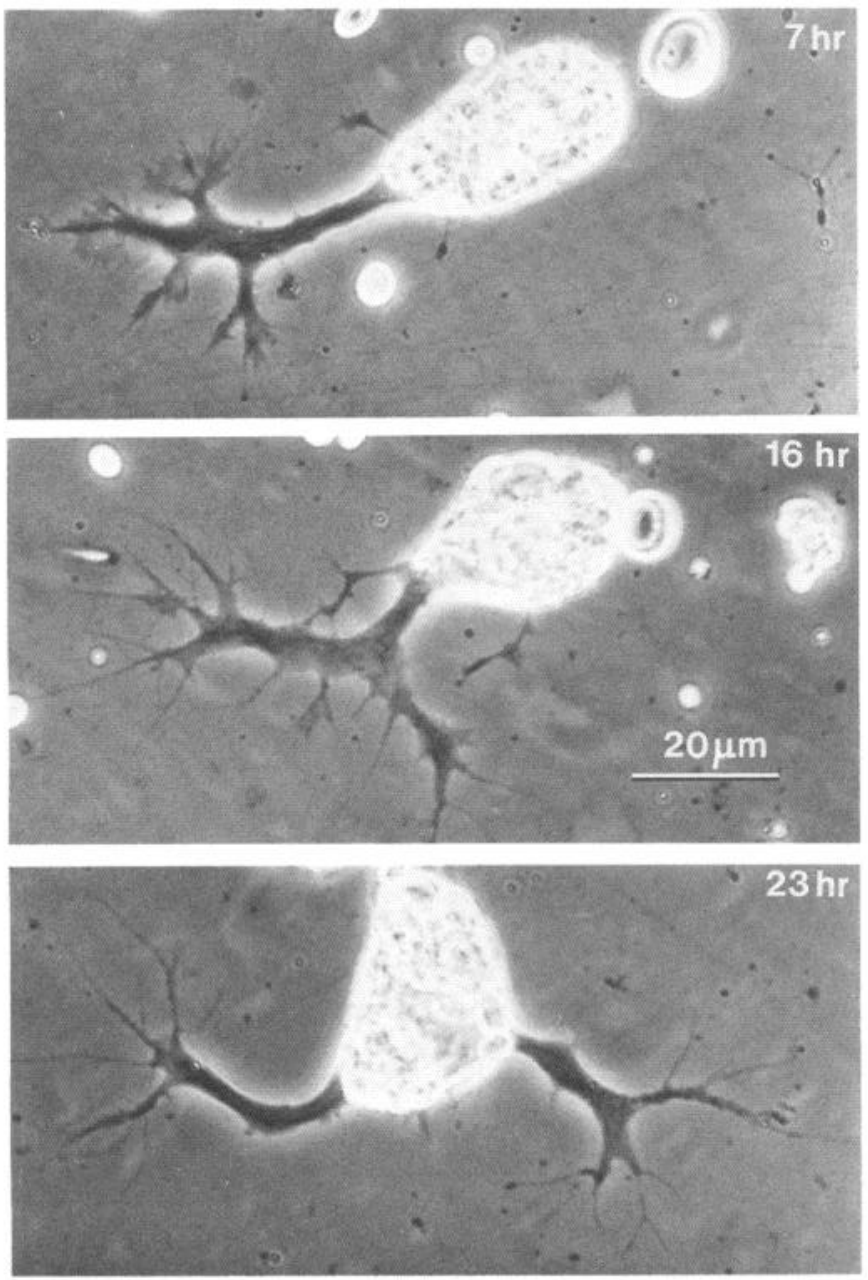

Figure 1. Phase-contrast photomicrographs of Xenopus spinal neurons at young, intermediate, and mature stages of development in culture.

1980; Bixby and Spitzer, 1984; Lamborghini and Iles, 1985). The neurons have refractile cell bodies $20-30 \mu \mathrm{m}$ in diameter and are identified morphologically after extension of neurites, which begins approximately $6 \mathrm{hr}$ after plating. Cells were examined between 6 and $29 \mathrm{hr}$ in culture. Cells with relatively short processes were chosen for voltage clamping to facilitate establishment of a good space-clamp (Fig. 1), and the currents recorded arose primarily from the cell body. Using this criterion for selection of neurons, no change in membrane capacitance was observed during the developmental period studied (Table 1). In a small number of trials, similar results were obtained

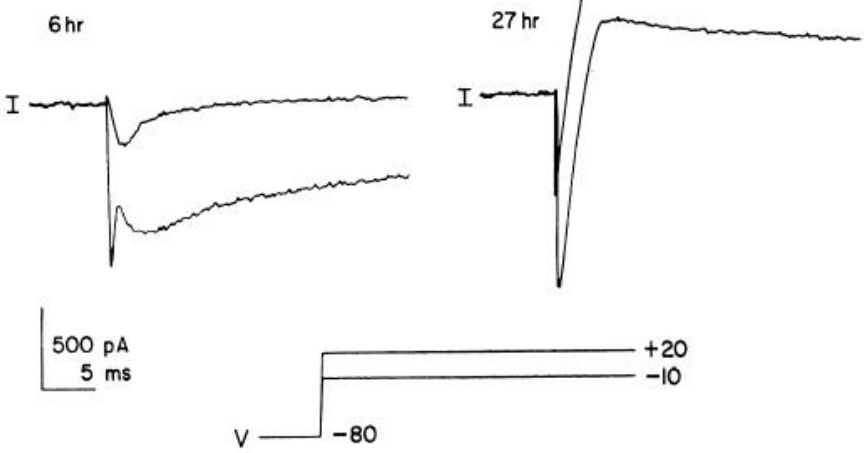

Figure 2. Expression of inward and outward currents in young and mature neurons. Records from 2 cells at 6 and $27 \mathrm{hr}$ in culture. The membrane potential was held at $-80 \mathrm{mV}$ and stepped to -10 and then $+20 \mathrm{mV}$; the current was sampled at $200 \mu \mathrm{sec}$ intervals. Recordings were made in an external saline containing $80 \mathrm{~mm} \mathrm{NaCl}, 10 \mathrm{~mm} \mathrm{CaCl}_{2}$, $5 \mathrm{mM} \mathrm{MgCl}_{2}, 3 \mathrm{~mm} \mathrm{KCl}$, and an intracellular solution with $100 \mathrm{~mm}$ $\mathrm{KCl}$. The larger depolarization elicits a sustained inward current from the young cell and a sustained outward current from the mature cell.

from cells with long neurites after the processes had been mechanically removed. Current records were accepted as well spaceclamped only when there was smoothly graded activation of inward current over a $25 \mathrm{mV}$ voltage range. Records were rejected if an abrupt activation threshold or notches appeared.

\section{Composite whole cell currents}

Whole-cell currents were first examined under conditions allowing expression of all the inward and outward currents (Fig. $2 ; n>10$ for young and mature cells). The external saline was similar to that used previously in recording the action potential, and the patch pipets contained a solution of $\mathrm{KCl}$ that approximated the normal intracellular potassium concentration (Spitzer, 1976). When a young cell is stepped to $-10 \mathrm{mV}$, only an inward transient current is elicited. When the cell is stepped to $+20 \mathrm{mV}$, both a transient inward current and a slowly decaying inward current are present (Fig. 2). This slowly declining net inward current may be a combination of inward current and a slowly activating outward current. In addition, voltage-clamp analysis of some young cells revealed a late outward current even at early times in culture, reflecting the large variability in the duration of the action potential at these stages (Blair, 1983; O'Dowd, 1983a). At late times, voltage steps to both -10 and $+20 \mathrm{mV}$ elicit a large transient inward current followed by an outward current (Fig. 2). There was no evidence of a sustained

Table 1. Time in culture affects density of sodium and potassium but not calcium currents nor cell size

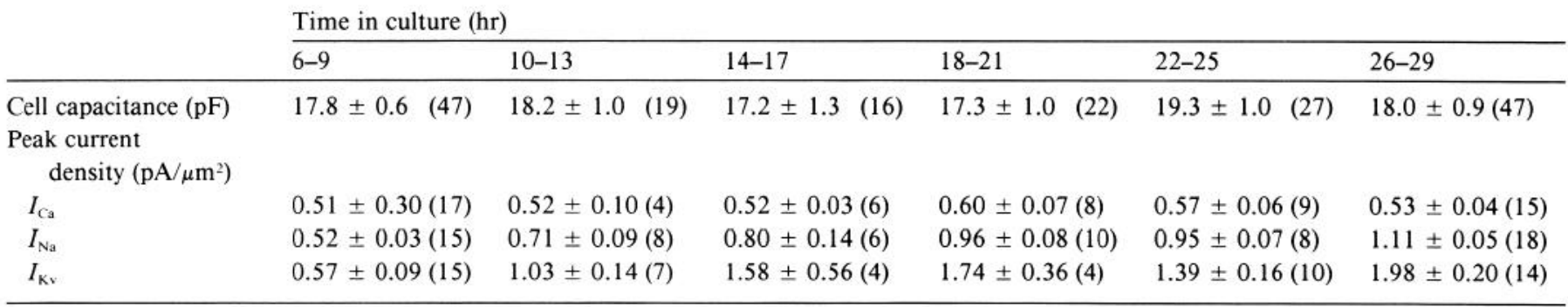

Values are mean $\pm \operatorname{SEM}(n)$. Data for $I_{\mathrm{kv}}$ were obtained at $+25 \mathrm{mV}$. 

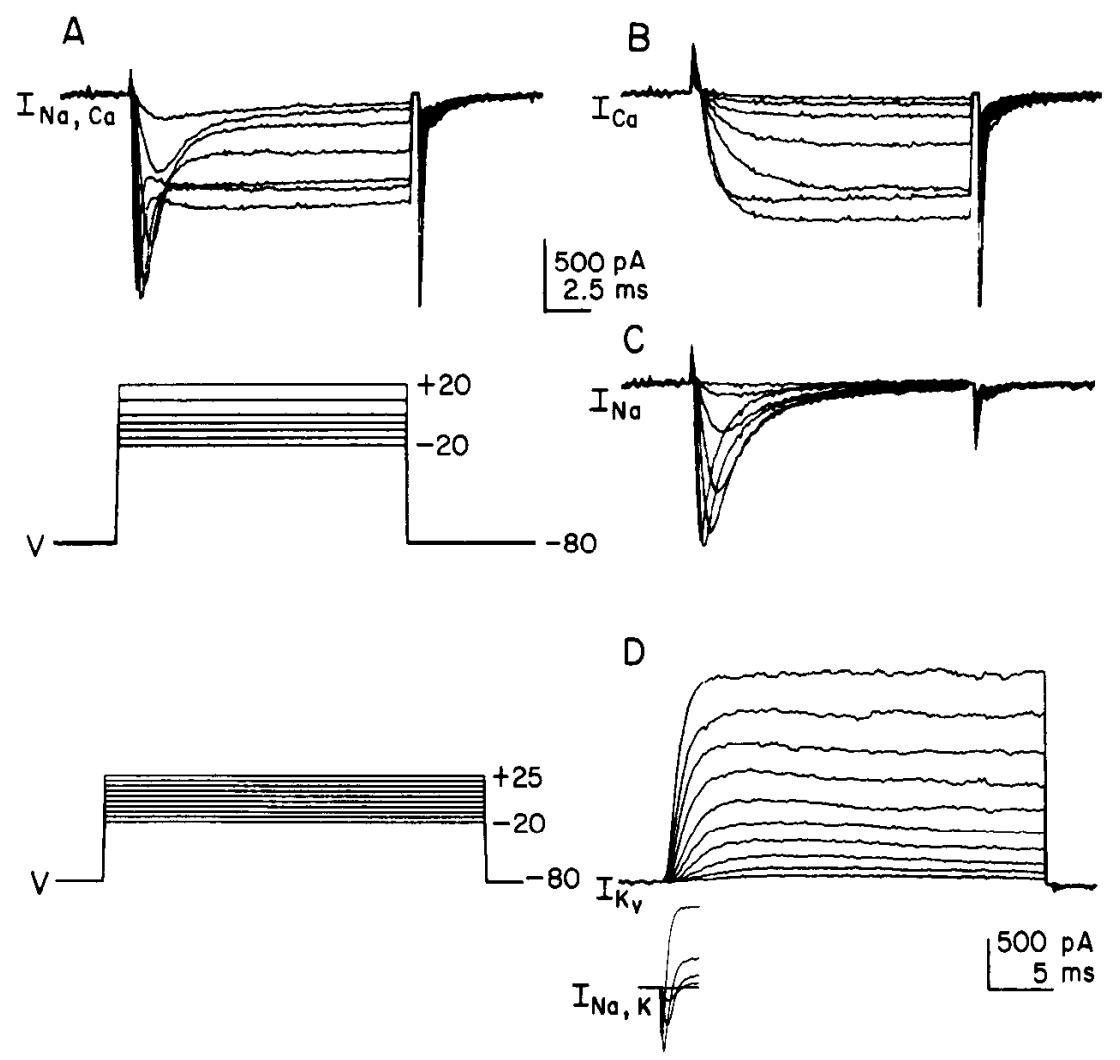

Figure 3. Isolation of voltage-dependent currents. $A-C$, Separation of sodium and calcium currents in a single cell at 17 hr in culture. Outward currents were blocked by internal $\mathrm{CsCl}$ and external TEACl, and inward currents were sampled at $100 \mu$ sec intervals; the first $400 \mu$ sec containing the capacitative transient following the onset and termination of the voltage step have been deleted. $A$, In normal saline, activation of both the fast transient sodium current $\left(I_{\mathrm{N}_{\mathrm{z}}}\right)$ and the maintained calcium current $\left(I_{\mathrm{r}_{\mathrm{a}}}\right)$ can be seen in response to a series of increasing, depolarizing voltage steps. $B$, When sodium in the external solution is replaced by Tris, only the slow maintained calcium current is present. $C$, Addition of 10 mm external cobalt blocks the calcium current, isolating the fast sodium current. $D$, Voltage-dependent potassium currents in a mature neuron at $22 \mathrm{hr}$ in culture. With a $\mathrm{KCl}$ internal solution and saline containing $10 \mathrm{mM} \mathrm{CoCl}_{2}$ and TTX (no added $\mathrm{CaCl}_{2}$ ), outward currents $\left(I_{\mathrm{Kv}}\right)$ in isolation are seen in response to a series of depolarizing voltage steps. Inset, Perfusion of the cell with saline containing no TTX reveals the sodium current, which activates smoothly and indicates adequate space clamp. The first $400 \mu \mathrm{sec}$ of the records that contain the capacitative transients following the onset and termination of the voltage step have been digitally removed.

inward current at any of the voltages examined. These observations of the composite whole-cell currents are consistent with previously reported differences in action potentials between young and old cells, and motivate analysis of the individual currents in isolation.

\section{Separation of currents}

To isolate inward currents, outward potassium currents were blocked by internal perfusion of cells with $\mathrm{CsCl}$ and addition of $\mathrm{TEACl}$ to the external solutions. Depolarizing voltage steps from a holding potential of $-80 \mathrm{mV}$ elicit both a transient and a maintained inward current (Fig. $3 A$ ). When sodium is removed from the external saline, only the slow maintained current is present (Fig. $3 B$ ). Addition of $10 \mathrm{~mm}$ cobalt to the normal saline blocks the maintained calcium current and isolates the fast, transient sodium current (Fig. 3C). Consistent with the effects of divalent cations on membrane surface charge, the addition of cobalt shifts the voltage dependence of the sodium current to a slightly more depolarized level $(5-10 \mathrm{mV})$. This shift was observed in both young and mature cells, and the data have not been corrected. In the presence of cobalt and the absence of sodium, the $I-V$ relation is linear between -40 and $+30 \mathrm{mV}$ (not illustrated). Use of sodium-free or cobalt-containing solutions thus makes possible the examination of calcium and sodium currents in isolation during development.
To isolate voltage-dependent outward currents in these neurons, inward sodium currents were blocked with TTX, and inward calcium currents were eliminated by the addition of $\mathrm{CoCl}_{2}$ and absence of calcium in the saline. Cells were internally dialyzed with a $\mathrm{KCl}$ solution. Recordings from cells with and without TTX allowed assessment of the quality of voltage control for fast inward currents of a magnitude similar to the slower outward potassium currents (Fig. 3,D.E). A uniform spatial distribution of sodium and potassium channels was assumed, and cells were discarded when the sodium currents were not well clamped. The isolation of calcium-dependent outward currents involved a subtraction protocol as well as blocking agents, and is presented later.

\section{Calcium currents}

Voltage-clamp records from neurons at early times in culture reveal the presence of substantial calcium currents, as would be expected from young cells exhibiting primarily calcium-dependent action potentials (Fig. 4). Although action potentials are largely sodium dependent at the later stages of development, a calcium component is revealed in older cells in the presence of external TEACl (Baccaglini and Spitzer, 1977). Nonetheless, it is possible that a decline in contribution of calcium to the action potential in mature neurons could be due to changes in the underlying calcium current. Accordingly, calcium current den- 

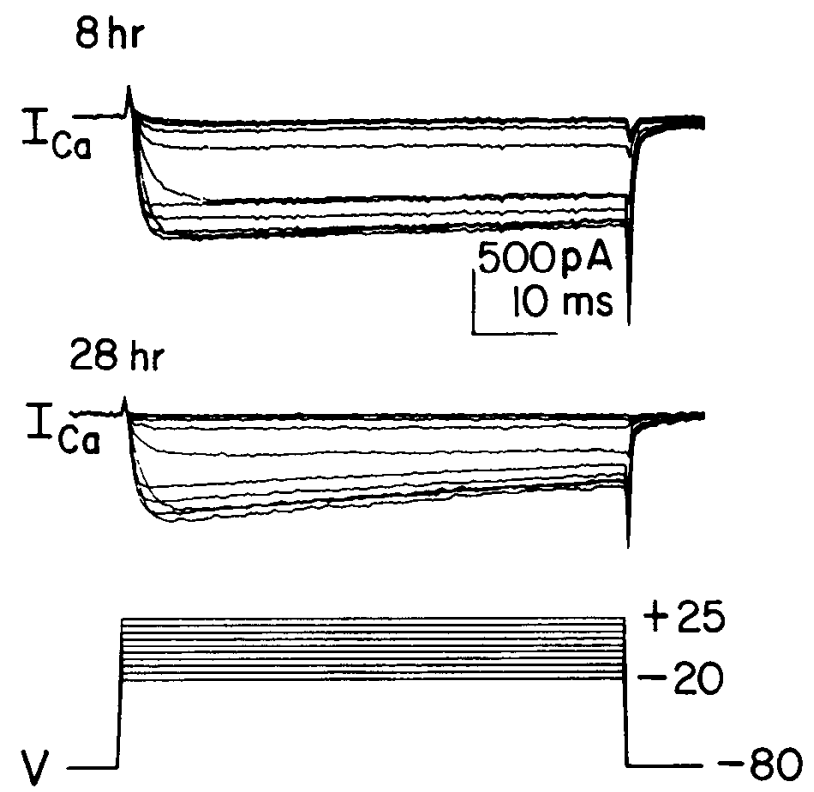

Figure 4. Development of calcium currents $\left(I_{\mathrm{Ca}}\right)$. Calcium currents of the same amplitude are present in neurons at early and late times in culture. Records from 2 cells. Current separation was achieved as indicated in Figure 3; each current trace is the average of 3 records. Figure 5 was obtained from records taken using this protocol.

sity, voltage dependence, and kinetics were examined at different developmental stages.

Development of $\mathrm{I}_{C a}$

Calcium currents are present in neurons at late times in culture (Fig. 4). The calcium currents at both early and late times are blocked by $10 \mathrm{mM} \mathrm{CoCl}_{2}$ in the bathing solution. Peak current density was computed as the peak current amplitude (in pA) per unit surface area (in $\mu \mathrm{m}^{2}$ ), obtained from measurement of cell capacitance (assuming $1 \mu \mathrm{F} / \mathrm{cm}^{2}$ ). The peak calcium current density does not change between 6 and $29 \mathrm{hr}$ in culture (Table 1).

The rate of washout was examined in 3 or more cells at early, middle, and late times, and there was no consistent difference in this parameter with age. In some cells there was no decrease in the peak current amplitude for up to $7 \mathrm{~min}$; in others, the calcium current was undetectable after only a few minutes.

\section{Voltage dependence and activation kinetics of calcium current}

$I-V$ curves were constructed to examine the voltage dependence of this current. The $I-V$ plots for young and mature cells overlap throughout the voltage range examined (Fig. $5 A$ ). The calcium current in Xenopus spinal neurons rises to a maximal amplitude, which is maintained at a relatively constant level for the first $15 \mathrm{msec}$ (Fig. 4). The activation kinetics of the calcium current can thus be examined, as there is little contamination by inactivation over this time period. The time to half-maximal current (in msec) is plotted as a function of voltage for both early and late cells (Fig. $5 B$ ), and these plots overlap in the voltage range examined $(-5$ to $+30 \mathrm{mV})$.

\section{Decline in calcium current during long voltage-clamp steps}

Distinct from washout of the calcium current, some cells exhibit a significant decrease in the amount of calcium current during a voltage step of long duration (Fig. 4). As noted above, the calcium current shows little or no decrease over the first $15 \mathrm{msec}$ of maintained voltage steps. Long-duration $(60 \mathrm{msec})$ voltage steps to voltages between -5 and $+5 \mathrm{mV}$ also elicit calcium current responses of relatively constant amplitude throughout the step. However, calcium currents evoked by long-duration voltage steps to more depolarized levels (between +10 and +30 $\mathrm{mV}$ ) show a significant decline in current amplitude over 60 msec. This was quantified by examining in each cell the current record corresponding to the voltage step that produced the maximal calcium current. The decline in calcium current, expressed as a percentage, was calculated as the ratio of the current amplitude at $60 \mathrm{msec}$ to the peak current amplitude. The mean decline plotted as a function of developmental age reveals that there is an increase in this parameter as the cells mature (Fig. $5 C$ ).

In addition to washout of peak calcium current, an increase in the stimulus-dependent decay of calcium current increases with recording time. Therefore, the possibility that the rate of washout of this parameter was different in young and mature cells was investigated. It was found that there was no consistent developmental change in the 9 cells examined between 6 and $27 \mathrm{hr}$ in culture.

\section{Sodium currents}

Although action potentials are primarily calcium-dependent at early times, a sodium component is revealed in the presence of cobalt at these stages of development (Blair, 1983; O'Dowd, 1983a ). The developmental change in ionic dependence of the action potential could be partially accounted for by changes in the properties of the underlying sodium current. The density, voltage dependence, and kinetics of the sodium current were therefore evaluated at different developmental stages.

\section{Development of $\mathbf{I}_{N a}$}

At early times in culture, small sodium currents are evoked by depolarizing voltage steps (Fig. $6 A$ ). Sodium currents elicited in older neurons are typically of larger amplitude (Fig. $6 B$ ). Sodium currents at all stages are suppressed by sodium-free saline (Fig. $3 B)$ or $1 \mu \mathrm{g} / \mathrm{ml}$ TTX $(n=10)$. The peak current density approximately doubles between 6 and $29 \mathrm{hr}$ in culture (Table 1).

A residual capacitative transient that remains after leak subtraction can be seen after the termination of the voltage step (Fig. 6). A similar transient at the onset of the voltage step would cause an underestimation of the peak sodium current density for the young (6-9 hr) cells by approximately 7\%; a similar 5\% underestimation would occur for the cells $26-29 \mathrm{hr}$ old. The values presented for peak current density are uncorrected. With voltage steps to potentials below $+30 \mathrm{mV}$, the error introduced by the capacitative transient has little effect on the voltage at which the peak current occurs. Accordingly, the $I-V$ curves were confined to test potentials below $+30 \mathrm{mV}$, from a holding potential of -80 .

\section{Voltage dependence of sodium currents}

The voltage dependence of the sodium current during development was analyzed in the same manner as the calcium current. The peak sodium current density increases between 6 and 29 hr (Table 1). When peak current amplitude elicited at each voltage step in a single cell is expressed as a percentage of the maximum peak current amplitude in that cell, the resulting $I-$ $V$ plots from maturc and young cclls ovcrlap throughout the 
A

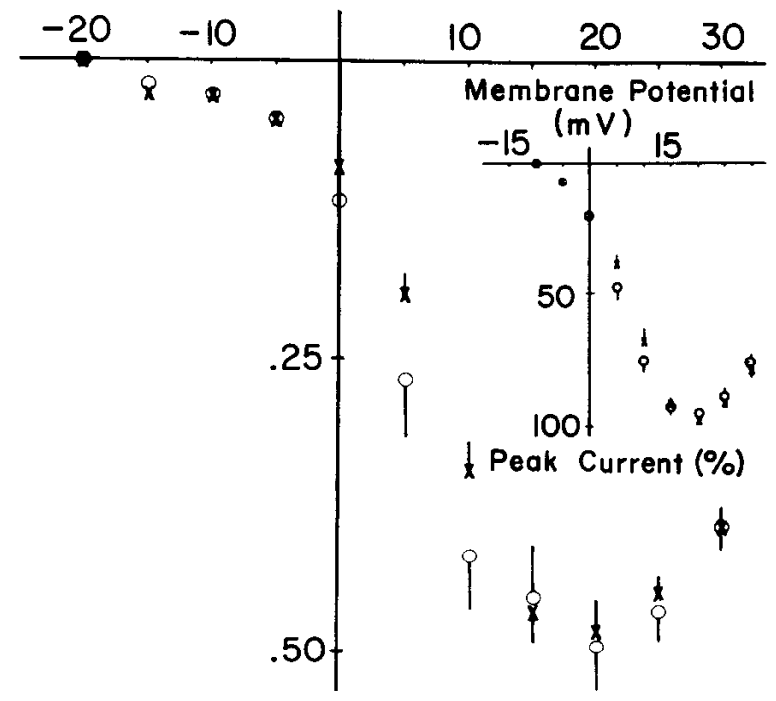

Peak Current Density $\left(\mathrm{pA} / \mu \mathrm{m}^{2}\right)$

$\mathrm{B}$
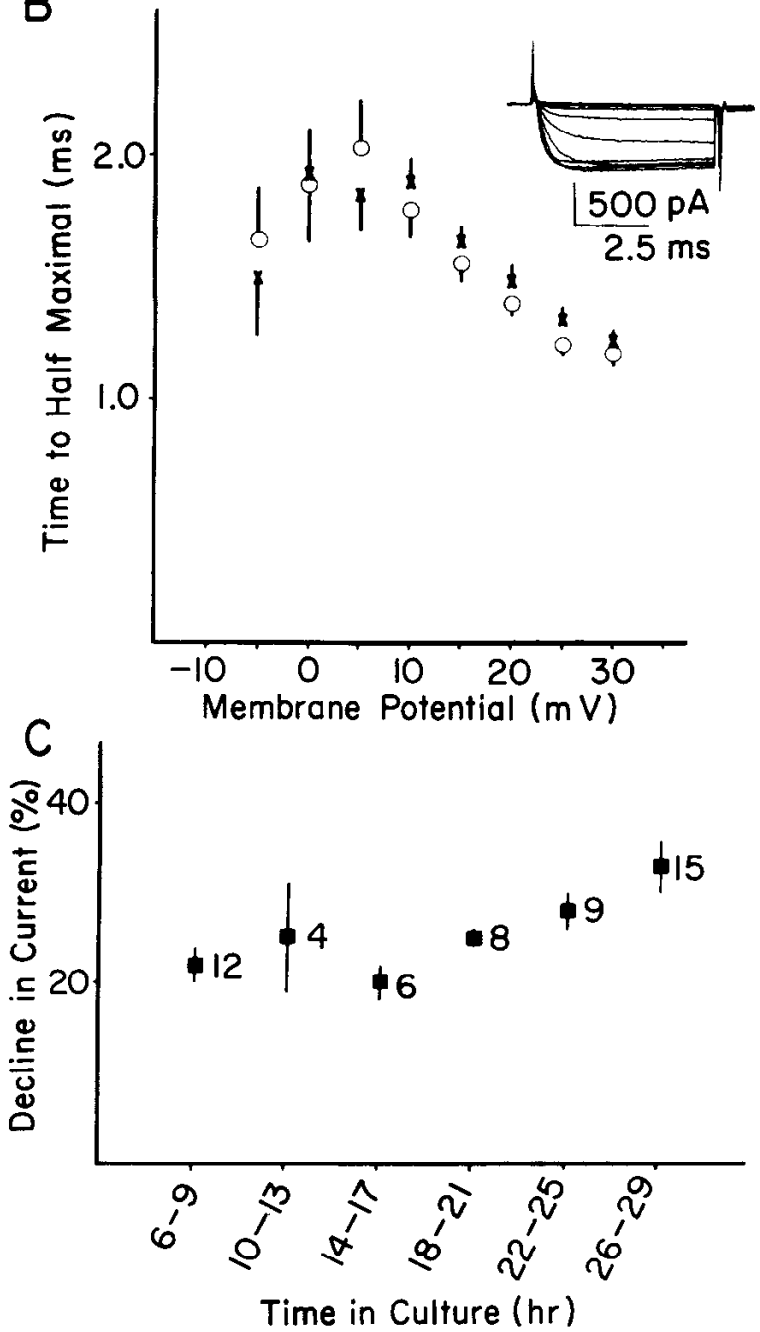

Figure 5. Properties of calcium currents. $A$, Voltage dependence of $I_{\mathrm{C}}$ at early and late times in culture. The peak current density is plotted as a function of membrane potential. Each point represents the mean peak current density at the given voltage for 12 or more cells at $6-9(X)$ and $26-29(\mathrm{O}) \mathrm{hr}$ in culture. Bars indicate SEM. Inset, The peak current amplitude at each voltage expressed as a percentage of the maximum

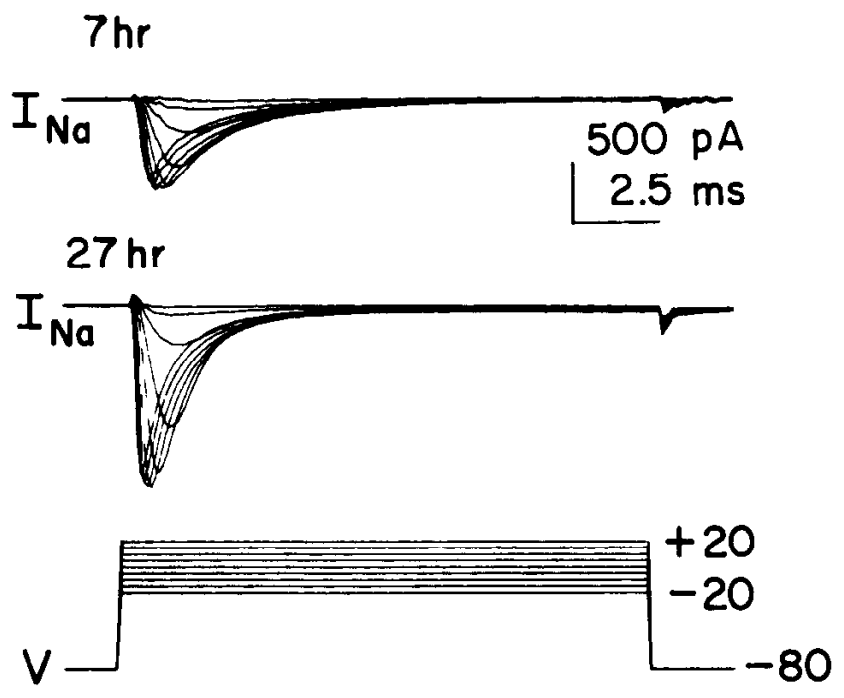

Figurc 6. Development of sodium currents $\left(I_{\mathrm{Na}}\right)$. Sodium currents are present at both early and late times in cultured neurons. Records from 2 cells. Current separation was achieved as indicated in Figure 3. Small sodium currents were present in neurons at the earliest times recordings could be made (6-9 hr). Larger sodium currents were elicited from neurons at late times $(26-29 \mathrm{hr})$ in culture. Each current trace is the average of 3 records. The data for Figures 7 and $8, A$ and $B$, were taken from records obtained with this stimulus protocol.

voltage range examined (Fig. $7 A$, inset), indicating a similar voltage dependence. The $I-V$ curves are shifted to a $5-10 \mathrm{mV}$ more depolarized level in the external solution containing cobalt compared with normal saline. This shift was seen in both young and mature cells and the values presented are uncorrected. This effect is consistent with the effects of elevated levels of external divalent cations on membrane surface charge.

\section{Sodium current kinetics}

The time-to-peak and the decay time constant of the sodium current were determined at different developmental stages. The time-to-peak, measured at each voltage for both early and late times in culture, is approximately $100 \mu \mathrm{sec}$ faster when the compiled data from older cells are compared to that from the young neurons (Fig. $7 B$ ). However, the magnitude of this shift is close to the time resolution of the recording system.

The decay time constant was obtained by fitting exponential distributions by eye to the falling phase of the transient current at each voltage. The currents for young cells are well fit by exponential distributions with a single time constant (Fig. $8 A$, left). In contrast, the currents elicited from older cells are often better fit with the sum of 2 exponentials (Fig. 8A, right). The time constant or constants of these fits were graphed as a func-

peak current amplitude in that cell, plotted as a function of membrane potential. Each point represents the mean percentage for 10 or more cells at early $(\mathrm{X})$ and late $(O)$ times in culture. $B$, Activation kinetics of calcium currents. The time to half-maximal current is plotted as a function of voltage for both early $(X)$ and late $(O)$ times (mean \pm SEM). $C$. Stimulus-dependent decay of calcium currents during development. The percentage decline in calcium current was calculated as the ratio of current amplitude at the end of a $60 \mathrm{msec}$ voltage step to the peak current amplitude. This parameter was measured only for the voltage step eliciting the maximal current record in each cell. The percentage decline, evaluated in $3 \mathrm{hr}$ time bins, is plotted as a function of age in culture (mean 1 SEM). Number of cells in each time bin is indicated. 

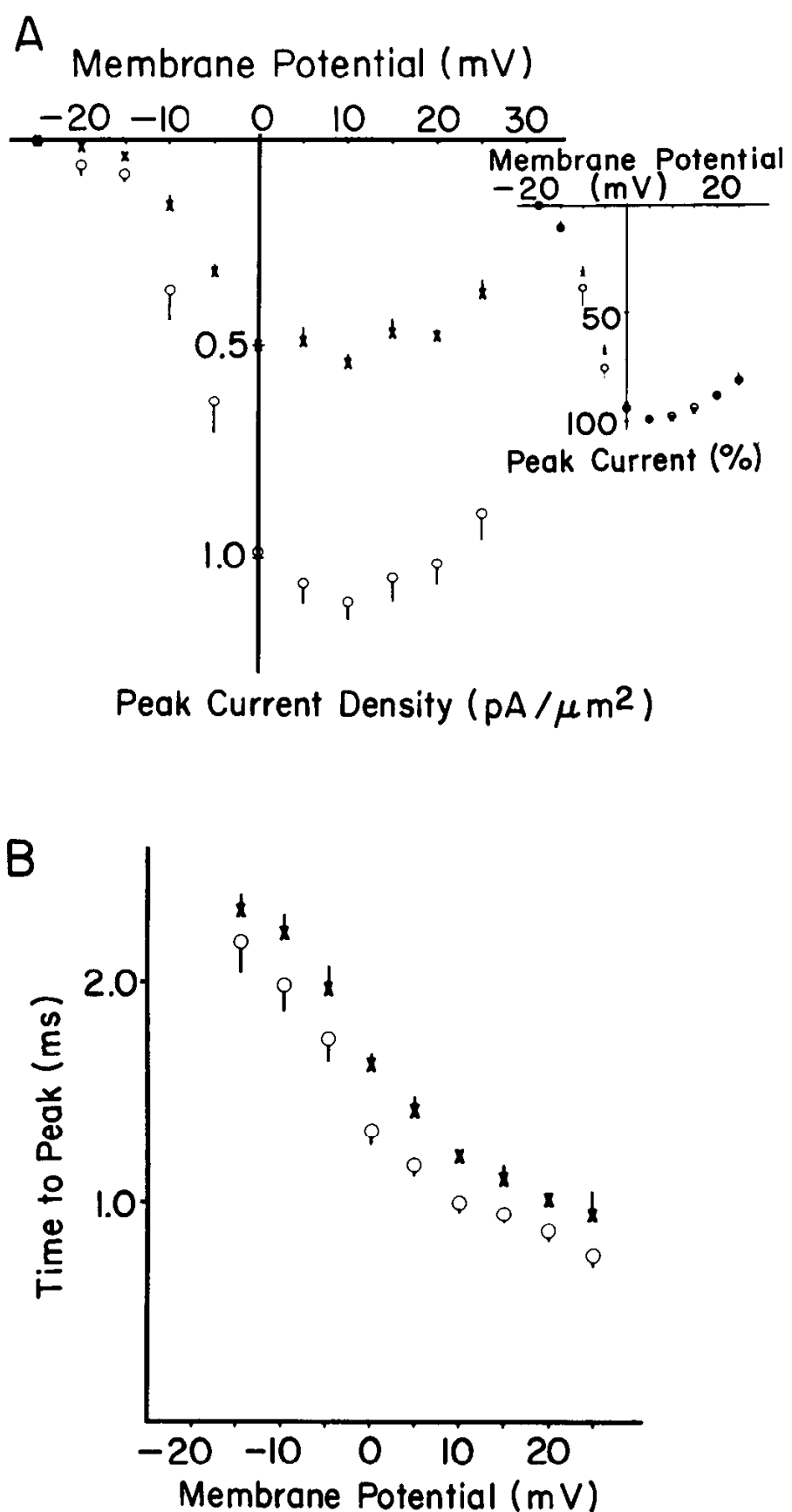

Figure 7. Voltage dependence of peak sodium current density and time to peak current. $A$, Current-voltage relation during development. The peak current density is plotted as a function of membrane voltage for young (6-9 hr; X) and mature (26-29 hr; O) cells. Each point represents the mean peak current density at the given voltage for at least 11 cells. Bars indicate SEM. Inset, The peak current amplitude at each voltage expressed as a percentage of the maximum peak current amplitude in that cell is plotted as a function of membrane potential. Each point represents the mean percentage for at least 9 cells at early $(X)$ and late $(O)$ times in culture. $B$, Time-to-peak of sodium current as a function of membrane potential at 2 stages of development. Each point represents the mean \pm SEM of time-to-peak at the given voltage for 9 or more cells at 6-9 $\mathrm{hr}(\mathrm{X})$ and $26-29 \mathrm{hr}(\mathrm{O})$. Time-to-peak values between 0 and $+20 \mathrm{mV}$ are significantly different at the $p \leq 0.05$ level by the Student's $t$-test.

tion of voltage for mature cells and young cells (Fig. $8 B$ ). The filled squares represent data from 4 young cells. The triangles are the data from 5 mature cells, with the filled symbols representing the time constant of the fit to the slower component seen at all voltages. This slow component is similar to that seen in young cells. The open triangles are the fits to the fast component of decay appearing only in the older cells at voltages positive to $-10 \mathrm{mV}$.

Inactivation was further examined using a prepulse protocol (Hodgkin and Huxley, 1952b). Cells were held at a resting potential of $-80 \mathrm{mV}$ and stepped to a test potential of $+5 \mathrm{mV}$ following a conditioning prepulse. The voltage and duration of the prepulse were varied, and the sodium current elicited at the test potential for a given prepulse was normalized to the sodium current evoked when no conditioning prepulse was applied. This value is expressed as a function of prepulse potential for 3 prepulse durations at 2 developmental stages (Fig. $8 \mathrm{C}$ ). As can be seen from these data, fitted by eye with Boltzmann's distributions, the values for young and mature cells are not different at any of the prepulse durations examined. The equivalent gating charge for each of these curves is approximately 3.5, while the half-maximal voltages shift in the hyperpolarizing direction as the prepulse duration increases. These data indicate the presence of a slow inactivation mechanism; the duration of the prepulse required to produce steady-state inactivation was not examined.

\section{Voltage-dependent potassium currents \\ Development of $\mathrm{I}_{K r}$}

Voltage-dependent potassium current was present in the youngest cells examined (Fig. 9). Both the amplitude and kinetics of activation of $I_{\mathrm{Kv}}$ increased during development (compare Fig. 9, $A$ and $B$ ). Application of external TEACl at $10 \mu \mathrm{M}$ caused at most a $10 \%$ reduction of this current $(n=5)$; it was further, but in no case completely, blocked by concentrations up to $20 \mathrm{~mm}$ $(n=5)$. In experiments during which the membrane was repolarized to different holding potentials after activation of $I_{\mathrm{K} v}$, the tail currents were observed to reverse near $-80 \mathrm{mV}\left(E_{\mathrm{K}} \approx\right.$ $-90 \mathrm{mV}$; see Figs. $10 \mathrm{C}$ and $11 C$ ). The current density, voltage dependence, and kinetics of this current were examined during development.

\section{Voltage dependence of $\mathbf{I}_{K_{v}}$}

Current-voltage curves were generated by plotting the peak current density during a $30 \mathrm{msec}$ pulse as a function of voltage. The $I-V$ relation was examined at early $(6-9 \mathrm{hr})$, intermediate $(10-17 \mathrm{hr}$ ), and late (26-29 hr) times in culture (Fig. 10A). These curves demonstrate an increase in current density of more than 3 -fold during this period (see also Table 1). There is no apparent shift in the voltage dependence, as the curves overlap when normalized to the currents elicited at late times.

\section{$\mathrm{I}_{K^{\prime}}$ kinetics}

Time to half-maximal activation as a function of test potential decreases with age (Fig. 10B). The curves can all be made to superimpose with appropriate scaling, suggesting that the decrease in time to half-maximal is uniform over the voltage range examined. This change cannot be easily accounted for solely on the basis of an increase in channel density. Comparison of the values of time to half-maximal with those for current density at intermediate times reveals that the developmental increase in rate of activation of this current occurs more slowly than the developmental increase in current amplitude.

The time course of inactivation was examined by stepping both young and mature cells to various prepulse potentials and examining the current during a test pulse to $+20 \mathrm{mV}$. Little or no steady-state inactivation is apparent following prepulses 
A

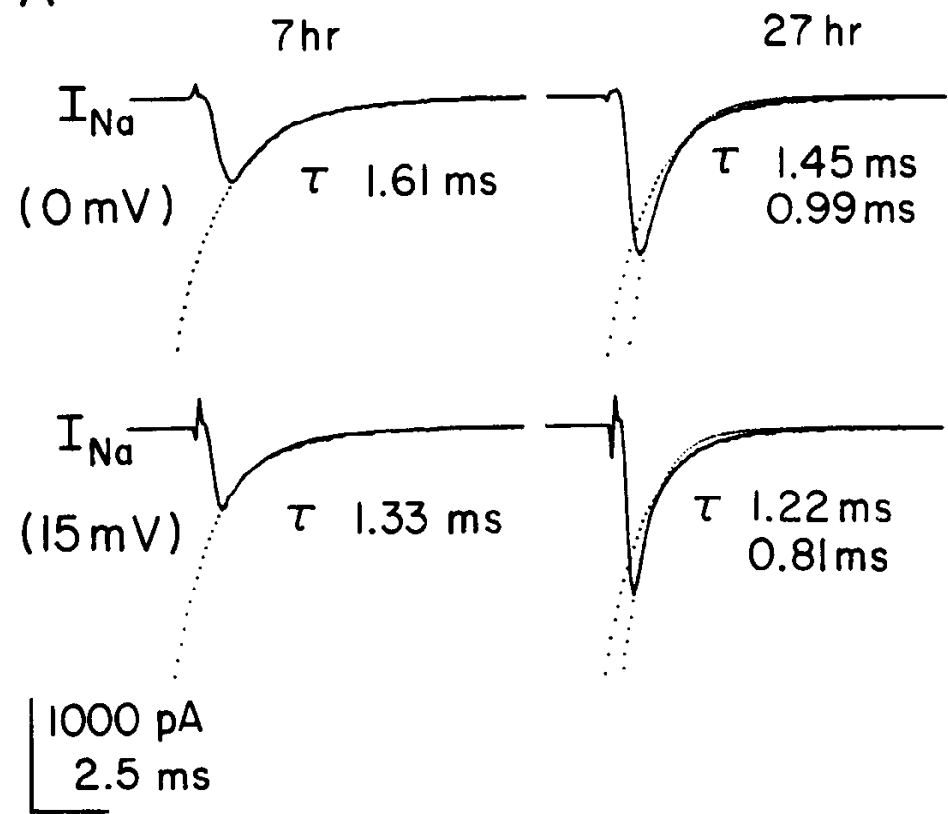

B Decay Time Constant (ms)

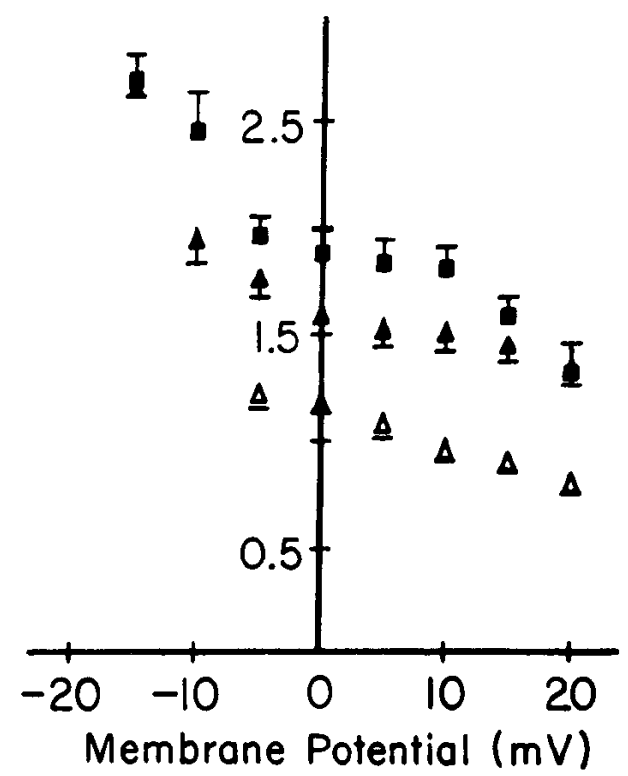

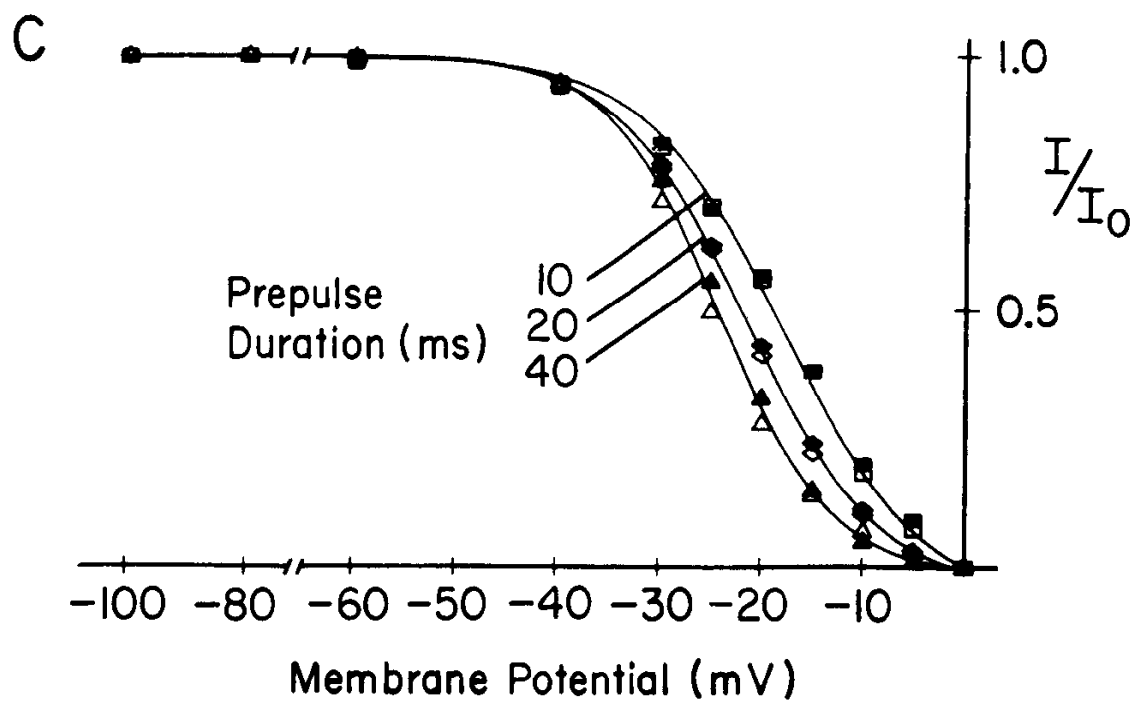

Figure 8. Kinetics of sodium currents. $A$, Decay time constants determined by fitting exponentials to the falling phase of the sodium current obtained at potentials of 0 and $15 \mathrm{mV}$ (dotted lines). The decay phase for young cells can be fit with single exponentials; currents of older cells are better fit by 2 exponentials. $B$, Mean decay time constants plotted as a function of voltage for four young cells $(\square)$ and five mature cells $(\Delta, \Delta)$. Bars indicate SEM. $C$, Properties of sodium current inactivation at early and late times in culture. The ratio of the peak sodium current amplitude at a test potential of $+5 \mathrm{mV}$ in the presence and absence of a prepulse was plotted as a function of prepulse potential for young and mature cells (6-9 hr, filled symbols; $26-29 \mathrm{hr}$, open symbols). Prepulse durations were $10(\mathbb{D}), 20(\diamond)$ and $40(\mathbf{\Delta})$ msec. Boltzmann's distributions were fitted to the data by eye. Each point represents the mean from 2-5 cells; SEMs for each point are between 0.01 and 0.07 .

ranging from -100 to $+20 \mathrm{mV}$, for as long as $100 \mathrm{msec}(n=$ 4 , young; $n=3$, mature; Fig. $10 C$ ). The pulse length examined corresponds to the mean action potential duration recorded intracellularly from young cells (Spitzer and Lamborghini, 1976; Blair, 1983; O’Dowd, 1983a).

\section{Calcium-dependent potassium currents}

\section{Separation of currents}

Calcium-dependent potassium currents were isolated by a subtraction protocol. Currents representing the sum of $I_{\mathrm{Kv}}$ and $I_{\mathrm{Kc}}$ were obtained with an external calcium concentration of 100 $\mu \mathrm{M}$ (Fig. $11 \mathrm{~A}$ ) in lieu of the $10 \mathrm{mM}$ used in study of calcium currents. Under these conditions, the macroscopic inward calcium current was less than 100 pA ( $n=8$ of 9 ). This small calcium current was then blocked by replacement of the external calcium with $500 \mu \mathrm{M}$ cadmium instcad of $10 \mathrm{mM}$ cobalt, to more nearly match the screening of membrane surface charge by 100 $\mu \mathrm{M}$ calcium. This procedure reduced the amplitude of the outward currents recorded from the same cells $\left(I_{\mathrm{Kv}}\right.$, Fig. $\left.11 A\right)$. Digital subtraction of the records obtained in the presence of cadmium from those obtained in the presence of calcium revealed a calcium-dependent outward current $\left(I_{\mathrm{Kc}}\right)$. In tests of this isolation protocol, currents with a similar peak and plateau profile were generated by the same subtraction procedure when $10 \mathrm{mM}$ cobalt was used instead of $500 \mu \mathrm{M}$ cadmium. Furthermore, these currents were not systematically affected by the order of presentation of the divalent cations. The fast, transient, and inactivating peak is referred to as $I_{\mathrm{Kci}}$. The noninactivating, sus- 


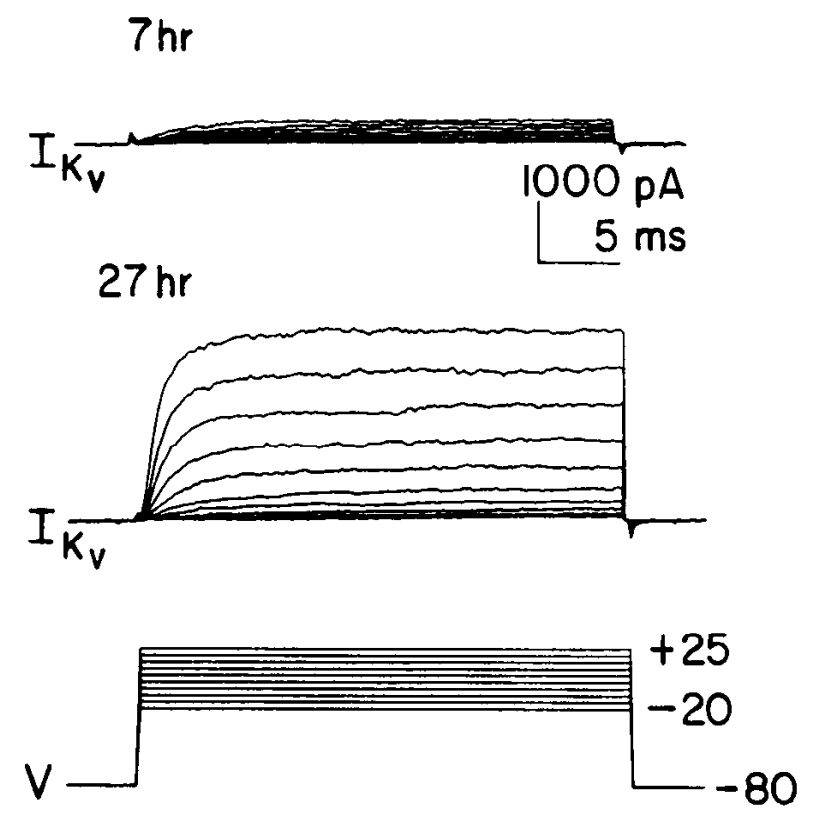

Figure 9. Development of voltage-dependent potassium currents $\left(I_{\mathrm{Kv}}\right)$. These currents are present at both early and late times in cultured neurons. Records from 2 cells. Current separation was accomplished as indicated in Figure $3 D$. Small currents were elicited from neurons at the earliest stages examined $(7 \mathrm{hr})$. Larger, faster currents were elicited at late times $(27 \mathrm{hr})$. The data for Figure $10, A$ and $B$, were taken from records obtained by this protocol.

tained plateau is designated $I_{\mathrm{Kcs}}$. These appear to constitute separate components since they are activated at different voltages and differ in their inactivation properties (Ribera and Spitzer, 1987a). These currents are also reduced, but not blocked, by micromolar concentrations of TEA (Ribera and Spitzer, 1987a), which do not affect $I_{\mathrm{Kv}}$. Although these currents were obtained with calcium concentrations lower than those of standard saline, their developmental properties reflect the state of neuronal differentiation.

The magnitude of $I_{\mathrm{Kci}}$ and $I_{\mathrm{Kcs}}$ exhibited a dependence on the external calcium concentration $(n=5)$. In mature cells, both currents were consistently elicited in the presence of $100 \mu \mathrm{M}$ calcium. When the external calcium concentration was lowered to $10 \mu \mathrm{M}$, the currents were smaller. Further reduction of the external calcium to $1 \mu \mathrm{M}$ resulted in undetectable calcium-dependent currents (Fig. $11 B$ ). The percentage reduction in current amplitude is larger at more depolarized potentials $(n=3$; not illustrated). Furthermore, the calcium-dependent currents ran down at a variable rate from cell to cell, but in the range consistent with calcium current washout (5-15 $\mathrm{min})$.

\section{Ion selectivity of $\mathbf{I}_{K}$}

The observation that all outward currents activated in the voltage range between -30 and $+30 \mathrm{mV}$ are blocked by the com-

Figure 10. Properties of voltage-dependent potassium current $\left(I_{\mathrm{Kv}}\right) . A$, Voltage dependence of $I_{\mathrm{Kv}}$ during development. The peak current density achieved during a $30 \mathrm{msec}$ voltage step is plotted as a function of membrane potential for young $(6-9 \mathrm{hr}, \Delta)$, intermediate $(10-13 \mathrm{hr}, \square)$, and mature $(26-29 \mathrm{hr}, 0)$ cells. Each point represents the mean value at that voltage for 10 or more cells. Bars indicate SEM. B, Activation kinetics of $I_{\mathrm{K} v}$ during development. The time to half-maximal is plotted as a function of voltage for young $(\triangle)$, intermediate $(\square)$, and mature $(O)$
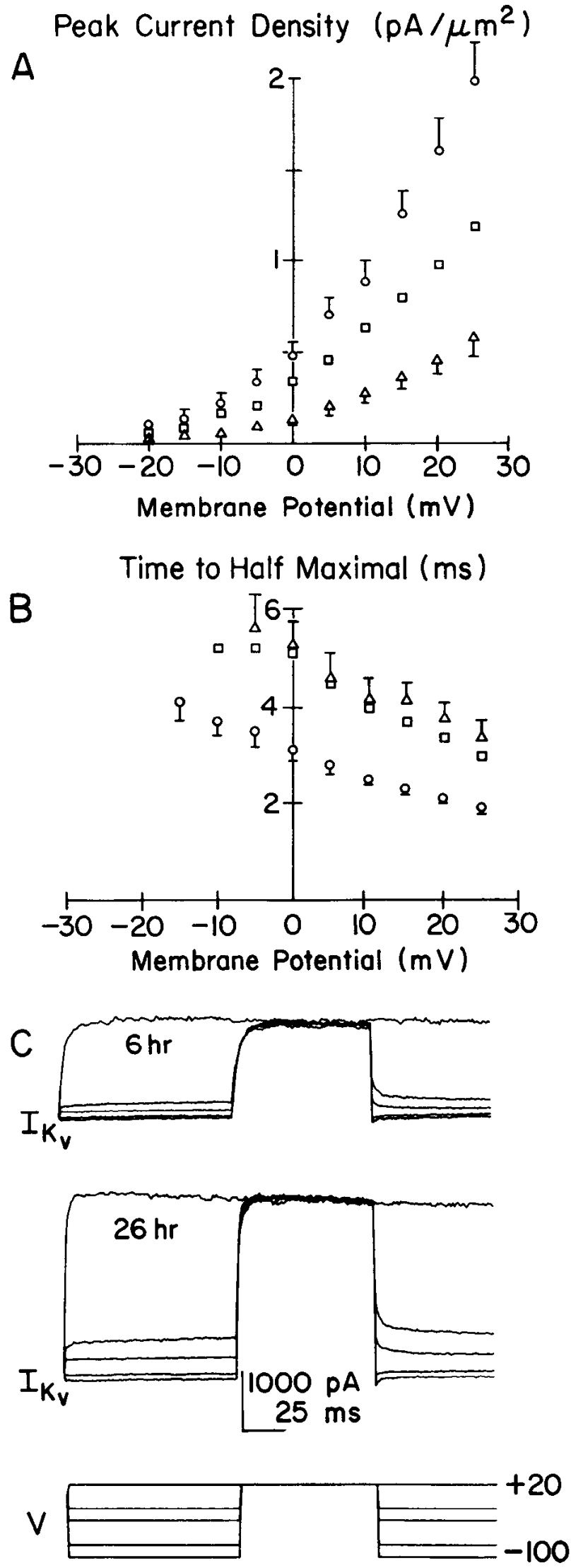

cells. Values are the mean $\pm \mathrm{SEM}$ for 10 or more cells. $C, I_{\mathrm{Kv}}$ shows little or no inactivation during sustained depolarizations. Records from a young ( $6 \mathrm{hr}$ in culture) and a mature $(26 \mathrm{hr}$ ) neuron. Cells were held at potentials of $-100,-80,-40,-20$, and stepped to $+20 \mathrm{mV}$ for $100 \mathrm{msec}$, or held at $+20 \mathrm{mV}$ for $250 \mathrm{msec}$. Voltage commands were presented at a frequency of $1 \mathrm{~Hz}$. 

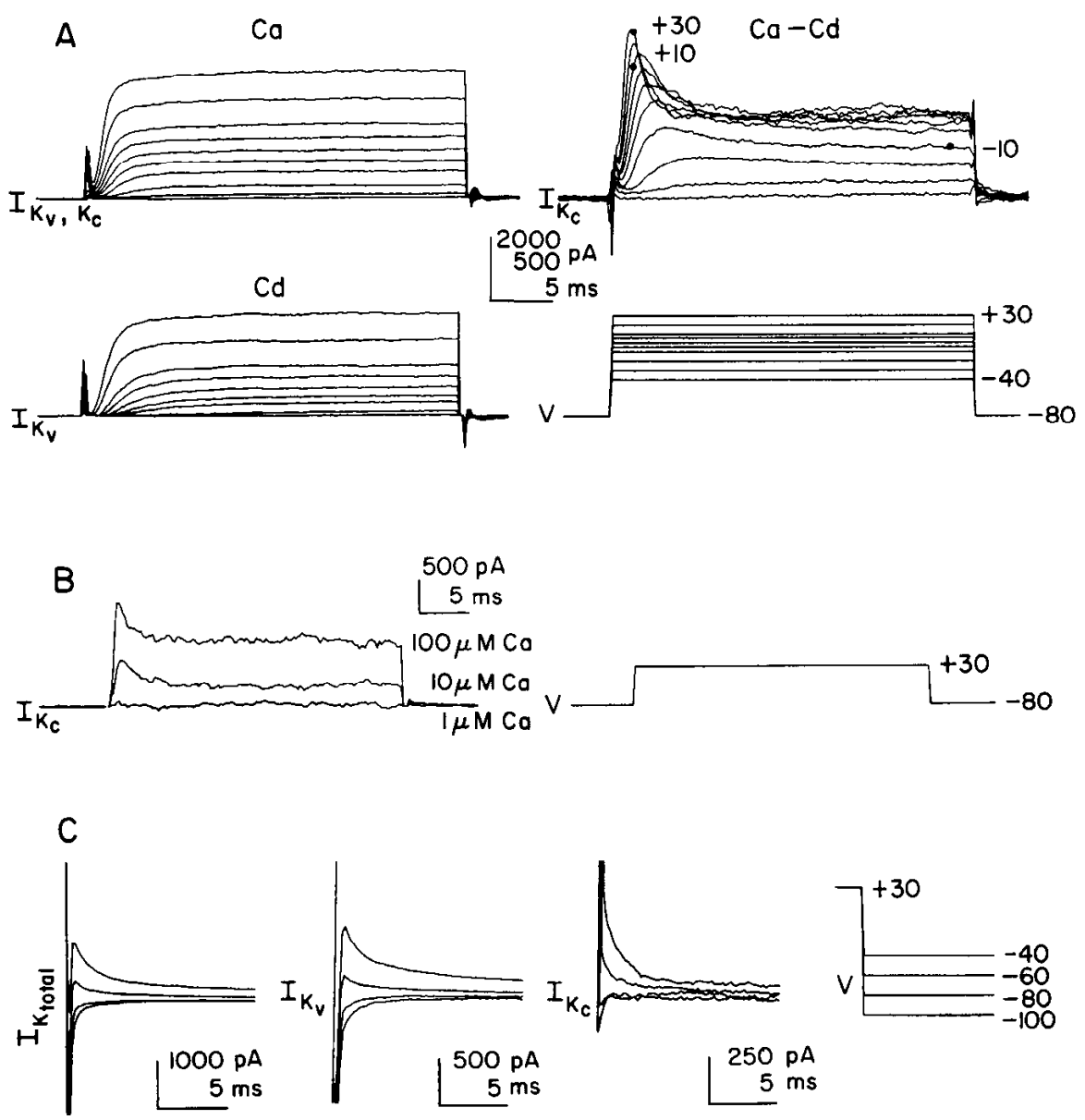

Figure 11. Isolation of calcium- and voltage-dependent potassium currents $\left(I_{\mathrm{Kc}}\right) . A$, In saline containing $100 \mu \mathrm{M}$ CaCl ${ }_{2}$ and TTX, outward currents are elicited (top left) by depolarizing voltage commands (bottom right). Control experiments showed that this concentration of calcium produces an inward current less than $100 \mathrm{pA}$. When the same cell is exposed to saline containing $500 \mu \mathrm{M} \mathrm{CdCl}_{2}$ plus TTX (no added CaCl$)_{2}$, smaller, slower currents are obtained (bottom left). Subtraction of the second set of records from the first yields net outward currents which depend on both voltage and external calcium ( $I_{\mathrm{Kc}}$, top right; note change in current scale). Neuron at $26 \mathrm{hr}$ in culture. $B$, The amplitude of $I_{\mathrm{Kc}}$ depends on the external concentration of $\mathrm{CaCl}_{2}$. Records from one neuron, $25 \mathrm{hr}$ in culture. $I_{\mathrm{Kc}}$ was obtained by the subraction protocol illustrated in $A$. Calcium concentrations of 100,10 , and $1 \mu \mathrm{M}$ were achieved by varying the amount of $\mathrm{CaCl}_{2}$ added to $10 \mathrm{~mm}$ EGTA. The cell was held at $-80 \mathrm{mV}$ and stepped to depolarized potentials. Both the transient and the sustained components of the current elicited at $+30 \mathrm{mV}$ are decreased as [Ca $\mathrm{Ca}_{0}$ ] is reduced from 100 to $10 \mu \mathrm{M}$ and are absent in $1 \mu \mathrm{M}$. Upon return to $100 \mu \mathrm{M}$ Ca solutions, $\mathrm{I}_{\mathrm{Kc}}$ regained most of its amplitude. $C$, Tail currents reverse near the potassium equilibrium potential. All records from one neuron, at $21 \mathrm{hr}$ in culture. The membrane potential was held at $-80,-60,-100$, or -40 $\mathrm{mV}$ and stepped to $+30 \mathrm{mV}$ for $30 \mathrm{msec}$ to activate currents; upon repolarization to the holding potential, inward and outward tail currents were seen. The currents reverse close to $-80 \mathrm{mV}$. Left, $I_{\mathrm{K}}$ total $\left(I_{\mathrm{Kv}}\right.$ plus $\left.I_{\mathrm{Kc}}\right)$, obtained in the presence of $100 \mu \mathrm{M} \mathrm{CaCl}_{2}\left(\mathrm{see}\right.$ above); middle, $I_{\mathrm{Kv}}$, obtained in the presence of $500 \mu \mathrm{M} \mathrm{CdCl}_{2}$ (see above); right, $I_{\mathrm{Kcs}}$, obtained by subtraction of $I_{\mathrm{Kv}}$ from $I_{\mathrm{Ktotal}}$.

bination of internal cesium and external TEA indicates their dependence on potassium ions. The dependence of $I_{\mathrm{K}}$ on potassium was further examined by determining the reversal potential of tail currents. Repolarization to different potentials following a depolarizing command to $+30 \mathrm{mV}$ yielded inward tail currents at potentials negative to $-80 \mathrm{mV}$ and outward tail currents at more depolarized voltages. For $I_{\mathrm{Kv}}$ total $\left(I_{\mathrm{K}}+I_{\mathrm{Kc}}\right)$, $I_{\mathrm{Kv}}$ and for $I_{\mathrm{Kcs}}$ the tail currents reverse near $-80 \mathrm{mV}(n=9$; Figs. $10 C, 11 C$ ). This is close to the $E_{\mathrm{K}}$ of $\approx-90 \mathrm{mV}$. Other ions are unlikely to contribute significantly to these currents, since $E_{\mathrm{Na}}$ is positive and $E_{\mathrm{Cl}}$ is close to $0 \mathrm{mV}$. Analysis of the tail currents of $I_{\mathrm{Kci}}$ as well as $I_{\mathrm{Kcs}}$ demonstrates a similar dependence on potassium ions (Ribera and Spitzer, 1987a).

\section{Development of $\mathbf{I}_{K c}$}

$I_{\mathrm{Kci}}$ and $I_{\mathrm{Kcs}}$ were analyzed separately to assess developmental changes that are characteristic to each. The initial, inactivating component was absent in some young cells $(3 / 10,6-9 \mathrm{hr} ; 2 / 8$,
10-13 hr). Furthermore, in other young cells, $I_{\mathrm{Kci}}$ was evident only at the most depolarized voltages (Fig. 12A). In contrast, $I_{\mathrm{Kci}}$ recorded from older cells appeared at less depolarized potentials (generally $-10 \mathrm{mV}$; Fig. 12B). In addition, comparison indicates that the amplitude of $I_{\mathrm{Kci}}$ increases roughly 2 -fold during development ( $n=10$ at each age).

Different developmental characteristics were observed for $I_{\mathrm{Kcs}}$. Unlike $I_{\mathrm{Kci}}$, it was present in all cells regardless of age. The magnitude of $I_{\mathrm{kcs}}$ at the most depolarized voltages did not increase during development $(n=10$ at each stage; compare Fig. $12, A, B)$. Current-voltage plots corrected for scrics resistance errors show that $I_{\mathrm{Kcs}}$ exhibits pronounced rectification in older cells (not illustrated). The kinetics of $I_{\mathrm{Kc}}$ and $I_{\mathrm{Kcs}}$ were not evaluated separately, since the inactivation protocol used to distinguish the two (Ribera and Spitzer, 1987a) reduced $I_{\mathrm{Kci}}$ to a variable extent and may have altered the time course of $I_{\mathrm{Kcs}}$. However, the time to half-maximal for $I_{\mathrm{Kc}}$ did not change with developmental age (data not shown). 


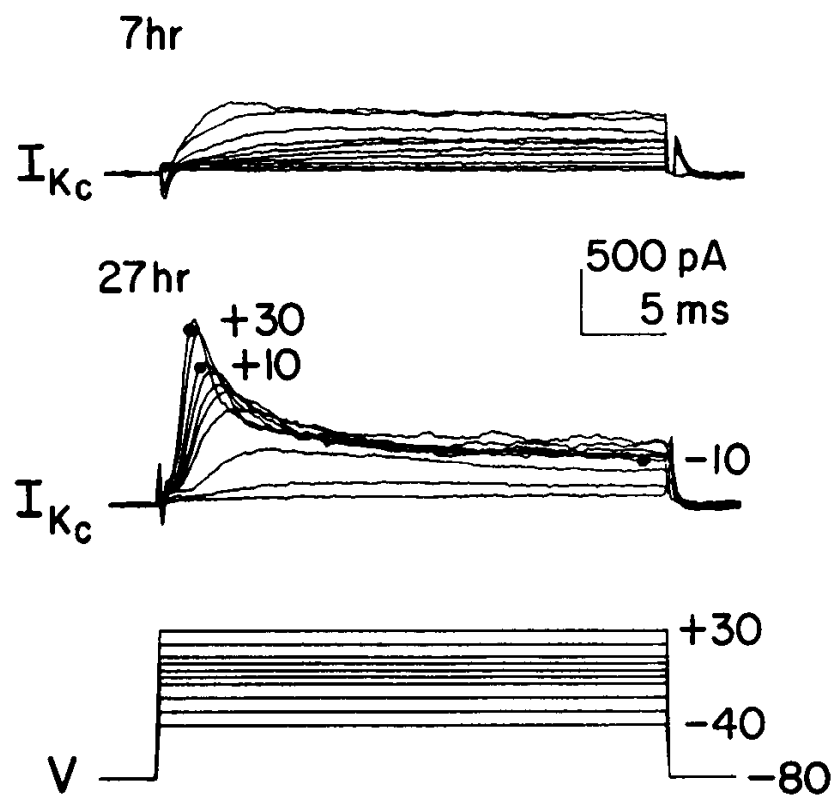

Figure 12. Development of calcium- and voltage-dependent potassium currents $\left(I_{\mathrm{kc}}\right)$. These currents are present at early and late times in cultured neurons. Records from 2 cells. The currents were isolated by the subtraction protocol shown in Figure $11 \mathrm{~A}$. Small currents were elicited at the earliest stages examined $(7 \mathrm{hr})$. The transient component was often present only at the most depolarized potentials and was absent from some cells. Larger currents were elicited at late times $(26 \mathrm{hr})$. The sustained component now shows marked rectification at the more depolarized potentials. The maximum series resistance error is $<10 \mathrm{mV}$.

\section{Discussion}

Properties of voltage-dependent currents from cultured Xenopus spinal neurons were investigated with the aim of detailing the events underlying the developmental change in ionic dependence of the action potential. Since a shift from a primarily calcium-dependent action potential to a largely sodium-dependent one occurs between 6 and $29 \mathrm{hr}$ in culture, properties of the macroscopic calcium, sodium, and potassium currents were examined during this period. In addition, developmental changes in the properties of a calcium-dependent potassium current were studied. For purposes of comparison with previous analyses, the ionic conditions under which the voltage-clamp experiments were performed were similar to those in which the development of the impulse was examined. However, dialysis of cells during whole-cell voltage-clamp may have removed components normally regulating the expression of currents.

\section{Calcium currents}

Calcium currents in these neurons are similar to those described in a number of other invertebrate and vertebrate preparations (Adams and Gage, 1978; Fenwick et al., 1982; Hume and Giles, 1983; Ishizuka et al., 1984). The lack of change in the peak calcium current density in Xenopus spinal neurons between 6 and $29 \mathrm{hr}$ in culture suggests that functional calcium channels are maintained at a constant density in the membrane throughout the time period examined, even though the calcium component of the action potential disappears. This result is consistent with previous studies of embryonic Xenopus neurons, in which intracellular recordings at late stages of development demonstrated that current pulses that elicit brief sodium-dependent action potentials can activate divalent cation-depen- dent components in the presence of solutions containing either TEACl or $\mathrm{BaCl}_{2}$; these agents allow observation of calcium currents by blocking the potassium currents that mask them (Spitzer and Baccaglini, 1976; Baccaglini and Spitzer, 1977; Willard, 1980). The calcium current density increases in developing $\mathrm{Am}$ bystoma spinal neurons, even though the calcium dependence of the impulse is reduced as in Xenopus (Barish, 1986). Calcium currents from avian neural crest cells show a developmental increase in magnitude, though these measurements have not been normalized for cell size. However, these cells, unlike amphibian neurons, exhibit a developmental increase in the calcium component of their action potential (Bader et al., 1983b).

The threshold of activation and peak of the calcium $I-V$ curve occur at a relatively depolarized level compared with those of the sodium current; similar results have been reported for the sodium and calcium currents seen in molluscan neurons (Kostyuk and Krishtal, 1977; Adams and Gage, 1978). Since neither of the $I-V$ curves shifts during development, the relative contributions of these currents to the action potential in maturing cells should not be affected by this parameter. Activation kinetics were examined by determining the time to half-maximal activation of calcium current during voltage steps of short duration $(15 \mathrm{msec})$, in which no significant inactivation was observed. The time course of activation of calcium current was much slower than that for sodium current, even at early times in culture. There was no significant shift in the time to halfmaximal current during development. As noted in other preparations, the calcium current elicited by a long-duration voltage step declines, with a variable time course (Kostyuk and Krishtal, 1977; Brown et al., 1981; Fukushima and Hagiwara, 1983; for review, see Hagiwara and Byerly, 1981). It is also possible that this decline in $I_{\mathrm{Ca}}$ is due to the presence of a slowly activating outward current that was not completely eliminated by the pharmacological blockers employed. The effect of this phenomenon on the calcium component of the action potential should vary according to the duration and maximal overshoot of the impulse. During calcium-dependent action potentials, the membrane conductance declines as a function of the impulse duration (Baccaglini and Spitzer, 1977). Young cells ( $8 \mathrm{hr}$ ) have long duration ( $\sim 90 \mathrm{msec}$ ) overshooting action potentials (Spitzer and Lamborghini, 1976; Blair, 1983; O’Dowd, 1983a), and termination of the impulse may be enhanced by the decline in the calcium current that occurs between 15 and $60 \mathrm{msec}$. However, older cells (10-30 hr) have impulses of shorter duration (2-20 $\mathrm{msec}$ ). Since the decline in calcium current is small during this interval, it will not greatly reduce the contribution of calcium influx to the action potential.

\section{Sodium currents}

Sodium currents in Xenopus spinal neurons have properties similar to those reported for other cells. The $I-V$ relation and steady-state inactivation resemble those seen in invertebrate and vertebrate neurons (Standen, 1975; Kostyuk and Krishtal, 1977; Adams and Gage, 1978; Fenwick et al., 1982; Stimers and Byerly, 1982; Belardetti et al., 1986). The kinetic properties of this current are also in the same range as those reported for other cells (Fenwick et al., 1982; Belardetti et al., 1986). The sodium current density doubles between 6 and $29 \mathrm{hr}$ in culture. Similar changes in density have been reported in other systems (Bader et al., 1983a, b; Westbrook and Brenneman, 1984; Barish, 1986; Huguenard et al., 1986; MacDermotl and Westbrook, 
1986; Sakaguchi, 1986). A developmental increase in the number of channels, the single-channel conductance, and/or the probability of being open could account for the observed increase in peak current density. In addition to changes in density, there are also changes in the kinetics of this current. The time to peak current decreases by approximately $100 \mu \mathrm{sec}$ over most of the voltage range examined. A fast component in the decay time constant of the sodium current appears during development. Young cells have a single relatively slow decay time constant at all voltages, while older cells develop a fast component and retain a slow component. Recording of single-channel currents may indicate whether changes in kinetics or the appearance of new channel classes account for the maturation of the whole cell currents.

Could these changes in sodium current density and kinetics contribute to the decrease in duration and shift in ionic dependence of the action potential? Comparison of the time course of sodium currents from young and old cells indicates that throughout a voltage step the older cells generate larger currents than the younger cells. This is consistent with the increasing rate of rise and the appearance of an overshooting sodium component in the developing action potential. Furthermore, the larger and more rapidly activated sodium currents in older cells could activate potassium conductances more briskly; repolarization of the membrane would occur more quickly and reduce the contribution to the action potential of the more slowly activated calcium current.

\section{Potassium currents}

Delayed rectifier potassium currents showed much larger changes than the inward currents. This suggests that outward currents, rather than inward currents, dictate the developmental changes of the action potential, even though the impulse is characterized by its dependence on inward currents. These outward currents were identified as largely potassium dependent, based upon reversal of tail currents at potentials near $E_{\mathrm{K}}$. In addition, they were blocked by internal cesium combined with external TEA. $I_{\mathrm{K} v}$ displays a voltage of activation, a $I-V$ relation, and relatively little inactivation, similar to other delayed rectifiers (Hodgkin and Huxley, 1952a; Thompson, 1977; Adams and Gage, 1978; Barrett et al., 1980; Barish, 1986). $I_{\mathrm{Kv}}$ was present at the earliest stages examined. During the developmental period studied, the mean current density of $I_{\mathrm{K} v}$ increased 3.5 -fold. In addition, a developmental decrease in time to half-maximal activation was observed. The developmental increase in current density occurs more rapidly than the increase in the rate of activation of this current: the current doubles in density prior to the major change in kinetics. These changes are consistent with the larger, faster currents in mature cells contributing to rapid repolarization and masking of the calcium component of the impulse. Similar observations have been reported for developing Ambystoma neurons (Barish, 1984; 1986). It was previously noted that the arrest in maturation of the impulse by inhibition of RNA and protein synthesis occurred without affecting the amplitude of delayed rectification (Blair, 1983; O'Dowd, 1983a). It is now evident that $I_{\mathrm{Kv}}$ was not activated by the range of hyperpolarized potentials that were examined with the technique previously employed, and that this result probably reflects a conductance which is now scored as a leak current. Channels that give rise to $I_{\mathrm{K} v}$ exhibit developmental changes in both their density and kinetics (Harris et al., 1986). The more rapid activation and increase in density of $I_{\mathrm{Kv}}$ may be attributable to the appearance of new channel classes, to changes in the properties of existing channels, or to increases in the density of channels.

\section{Calcium-dependent potassium currents}

Measurements of calcium- and voltage-dependent currents $\left(I_{\mathrm{Kc}}\right)$ were complicated by the requirement for delivery of calcium to the internal face of the membrane and the absence of a pharmacological blocking agent selective for the voltage-dependent potassium currents. The first difficulty was overcome by the use of a low level of external calcium, yielding an inward current that was small and not macroscopically detectable. The second difficulty was circumvented by subtraction of voltage-dependent currents from those elicited in the presence of calcium. A low level of cadmium $(500 \mu \mathrm{M})$ was used in preference to $10 \mathrm{mM}$ cobalt to more nearly match the effects of $100 \mu \mathrm{M}$ calcium on surface charge. As a consequence, calcium-dependent currents were studied under conditions different from those used for evaluation of other currents. Furthermore, the level of calcium used to elicit them was low compared with physiologic external calcium levels.

Both an inactivating and a sustained component of $I_{\mathrm{Kc}}$ have been identified $\left(I_{\mathrm{Kci}}, I_{\mathrm{Kcs}}\right.$; see also Ribera and Spitzer, 1987a). $I_{\mathrm{Kci}}$ is rapidly activated and inactivated, similar in these respects to A currents observed in other cells (Hagiwara et al., 1961; Connor and Stevens, 1971; Neher, 1971). Transient, as well as sustained, calcium-dependent potassium currents have been observed in other neurons (Meech, 1974; Barrett and Barrett, 1976; Siegelbaum and Tsien, 1980; Adams et al., 1982; MacDermott and Weight, 1982; Zbicz and Weight, 1985).

The 2 components of the calcium-dependent current have different developmental characteristics. $I_{\mathrm{Kci}}$ was not detected in some young cells; in others, $I_{\mathrm{Kei}}$ was apparent at only the most depolarized potentials. $I_{\mathrm{Kcs}}$ was detected in all cells examined; increased rectification is a feature of the development of this current. Similarly, a transient outward (A) current develops more slowly than $I_{\mathrm{K} v}$ in neurons from rat sympathetic ganglia (Nerbonne et al., 1986). In embryonic rat diencephalic neurons, these 2 currents appear at about the same time, and another transient (C) current develops later (Ahmed et al., 1986). The A current matures earlier than $I_{\mathrm{Kv}}$ in neurons from quail neural crest (Bader et al., 1985). Total outward currents recorded in the presence of calcium activated more rapidly than currents elicited in the absence of calcium, suggesting that the time to half-maximal current of $I_{\mathrm{Kc}}$ is less than that of $I_{\mathrm{K} v}$. No attempt was made to examine developmental changes in the inactivation of these currents. The differentiation of the 2 components of $I_{\mathrm{Kc}}$ probably reflects changes in the potassium currents themselves, rather than in the calcium currents leading to their activation, since calcium current density is stable during the period studied. $I_{\mathrm{Ca}}$ inactivates with long voltage pulses but on a time course slower than that of $I_{\mathrm{Kc}}$. A large potassium-selective channel $(\gamma=150$ pS), which is initially insensitive to calcium and acquires sensitivity at later stages, has been observed in single-channel recordings from these neurons (Blair and Dionne, 1985).

\section{Development of the action potential}

The results provide a qualitative understanding of the individual contributions of 4 voltage-dependent currents to the development of the action potential. Developmental changes in the sodium current contribute to the increasing sodium dependence 
of the action potential and may also be involved in changes in action potential duration. Loss of the calcium component is not due to changes in the underlying calcium current. However, both the increase in the density of $I_{\mathrm{Kv}}$ and $I_{\mathrm{Kc}}$ and in the activation ratc of $I_{\mathrm{Kv}}$ during development will result in increasing rates of action potential repolarization and loss of the calcium component. Barish (1986) has described increases in both current density and rate of activation of $I_{\mathrm{K} v}$ in embryonic Ambystoma neurons differentiating in culture. The action potential, reconstructed with a model incorporating the measured parameters of $I_{\mathrm{Kv}}$ and inward current, accounted qualitatively for the change in ionic dependence of the impulse; however, only a small decrease in its duration was predicted by the model (Barish, 1986).

As shown in several classes of vertebrate neurons, rapidly activating calcium-dependent potassium currents contribute to fast repolarization of the action potential (Adams et al., 1982; MacDermott and Weight, 1982; Zbicz and Weight, 1985; Storm, 1987). That potassium currents are involved in repolarization of the mature impulse is indicated by its prolongation by TEA (Baccaglini and Spitzer, 1977). The high sensitivity to TEA of calcium-dependent potassium currents in this system (Ribera and Spitzer, 1987a), as in others, suggests that they, as well as voltage-dependent potassium currents, play a role in the dcvelopmental reduction of impulse duration. Modeling of the developing inward and outward currents will be useful to determine if they can account quantitatively for the normal differentiation of the impulse in Xenopus spinal neurons, from a long duration (100 $\mathrm{msec})$, principally calcium-dependent action potential to a short-duration $(1 \mathrm{msec})$, primarily sodium dependent impulse. In addition, it will be interesting to determine which of these properties of the developing currents and underlying channels are affected by inhibitors of RNA and protein synthesis that arrest the normal maturation of the action potential (Blair, 1983; O'Dowd, 1983a). Recent work has shown that inhibition of RNA synthesis prevents both the developmental increase in current density and decrease in time to halfmaximal current of $I_{\mathrm{kv}}$ (Ribera and Spitzer, 1987b), without major effects on the development of $I_{\mathrm{Na}}$ and maintenance of $I_{\mathrm{Ca}}$ (O’Dowd, 1985).

\section{References}

Adams, D. J., and P. W. Gage (1978) Ionic currents in response to membrane depolarization in an Aplysia neurone. J. Physiol. (Lond.) 289: 115-141.

Adams, P. R., A. Constanti, D. A. Brown, and R. B. Clark (1982) Intracellular $\mathrm{Ca}^{2+}$ activates a fast voltage-sensitive $\mathrm{K}^{+}$current in vertebrate sympathetic neurones. Nature 296: 746-749.

Ahmed, Z., P. S. Walker, and R. E. Fellows (1983) Properties of neurons from dissociated fetal rat brain in serum-free culture. J. Neurosci. 3: 2448-2462.

Ahmed, Z., J. A. Connor, D. W. Tank, and R. E. Fellows (1986) Expression of membrane currents in rat diencephalic neurons in serum-frec culture. Dev. Brain Res. 28: 221-231.

Baccaglini, P. I. (1978) Action potentials of embryonic dorsal root ganglion neurones in Xenopus tadpoles. J. Physiol. (Lond.) 283: 585604.

Baccaglini, P. I., and N. C. Spitzer (1977) Developmental changes in the inward current of the action potential of Rohon-Beard neurones. J. Physiol. (Lond.) 271: 93-117.

Bader, C. R., D. Bertrand, and A. C. Kato (1983a) Membrane currents in a developing parasympathetic ganglion. Dev. Biol. 98: 515-519.

Bader, C. R., D. Bertrand, E. Dupin, and A. C. Kato (1983b) Development of electrical properties of cultured avian neural crest. Nature 305: 808-810.

Bader, C. R., D. Bertrand, and E. Dupin (1985) Voltage-dependent potassium currents in developing neurones from quail mesencephalic neural crest. J. Physiol. (Lond.) 366: 129-151.

Barish, M. E. (1984) Increase of outward currents during differentiation of amphibian neurons in vitro. Soc. Neurosci. Abstr. 10: 937.

Barish, M. E. (1986) Differentiation of voltage-gated potassium current and modulation of excitability in cultured amphibian spinal neurones. J. Physiol. (Lond.) 375: 229-250.

Barrett, E. F., and J. N. Barrett (1976) Separation of two voltagesensitive potassium currents, and demonstration of a tetrodotoxinresistant calcium current in frog motoneurones. J. Physiol. (Lond.) 255: 737-774

Barrett, E. F., J. N. Barrett, and W. E. Crill (1980) Voltage-sensitive outward currents in cat motoneurones. J. Physiol. (Lond.) 304: 251276.

Belardetti, F., S. Schacher, and S. A. Siegelbaum (1986) Action potentials, macroscopic and single channel currents recorded from growth cones of Aplysia neurones in culture. J. Physiol. (Lond.) 377: 289313.

Bixby, J. L., and N. C. Spitzer (1984) The appearance and developments of neurotransmitter sensitivity in Xenopus embryonic spinal neurones in vitro. J. Physiol. (Lond.) 353: 143-155.

Blair, L. A. C. (1983) The timing of protein synthesis required for the development of the sodium action potential in embryonic spinal neurons. J. Neurosci. 3: 1430-1436.

Blair, L. A. C., and V. E. Dionne (1985) Developmental acquisition of Ca-sensitivity of $\mathrm{K}$ channels in spinal neurones. Nature $315: 329$ 331

Brown, A. M., K. Morimoto, Y. Tsuda, and D. L. Wilson (1981) Calcium current-dependent and voltage-dependent inactivation of calcium channel in Helix aspersa. J. Physiol. (Lond.) 320: 193-218.

Byerly, L., and S. Hagiwara (1982) Calcium currents in internally perfused nerve cell bodies of Limnea stagnalis. J. Physiol. (Lond.) 322: 503-528.

Connor, J. A., and C. F. Stevens (1971) Voltage clamp studies of a transient outward membrane current in gastropod neural somata. $J$. Physiol. (Lond.) 213: 21-30.

Fenwick, E. M., A. Marty, and E. Neher (1982) Sodium and calcium channels in bovine chromaffin cells. J. Physiol. (Lond.) 331: 599635.

Fukuda, J., and M. Kameyama (1979) Enhancement of calcium spikes in nerve cells of adult mammals during neurite growth in tissue culture. Nature 279: 546-548.

Fukushima, Y., and S. Hagiwara (1983) Voltage-gated calcium channels in mouse myeloma cells. Proc. Natl. Acad. Sci. USA 80: 22402242

Hagiwara, S., and L. Byerly (1981) Calcium channel. Annu. Rev. Neurosci. 4: 69-125.

Hagiwara, S., K. Kusano, and N. Saito (1961) Membrane changes of Onchidium nerve cell in potassium-rich media. J. Physiol. (Lond.) 155: 470-489.

Hamill, O. P., A. Marty, E. Neher, B. Sakmann, and F. J. Sigworth (1981) Improved patch-clamp techniques for high resolution current recording from cells and cell-free membrane patches. Pfluegers Arch. 391: $85-100$

Harris, G. L., L. P. Henderson, and N. C. Spitzer (1986) Developmental changes in potassium channel properties in cultured amphibian spinal neurons. Soc. Neurosci. Abstr. 12: 952.

Hodgkin, A. I., and A. F. Huxley (1952a) Currents carried by sodium and potassium ions through the membrane of the giant axon of Loligo. J. Physiol. (Lond.) 116: 449-472.

Hodgkin, A. L., and A. F. Huxley (1952b) The dual effect of membrane potential on sodium conductance in the giant axon of Loligo. J. Physiol. (Lond.) 116: 497-506

Huguenard, J. R., O. P. Hamill, E. F. Enayati, and D. A. Prince (1986) Development of $\mathrm{Na}^{+}$conductance in neocortical neurons of the rat. Soc. Neurosci. Abstr. 12: 950.

IIume, J. R., and W. Giles (1983) Ionic currents in single isolated bullfrog atrial cells. J. Gen. Physiol. 81: 153-193.

Ishizuka, S., K. Hattori, and N. Akaike (1984) Separation of ionic currents in the somatic membrane of frog sensory neurons. J. Membr. Biol. 78: 19-28.

Kano, M. (1975) Development of excitability in embryonic chick skeletal muscle cells. J. Cell Physiol. 86: 503-510.

Kidokoro, Y. (1975) Sodium and calcium components of the action potential in a developing skeletal muscle cell line. J. Physiol. (Lond.) 244: $145-159$. 
Kostyuk, P. G., and O. A. Krishtal (1977) Separation of sodium and calcium currents in the somatic membrane of molluscan neurones. J. Physiol. (Lond.) 270: 545-568.

Lamborghini, J. E. (1980) Rohon-Beard cells and other large neurons in Xenopus embryos originate during gastrulation. J. Comp. Neurol. 189: 323-333.

Lamborghini, J. E., and A. Iles (1985) Development of a high-affinity GABA uptake system in embryonic amphibian spinal neurons. Dev. Biol. 112: 167-176.

MacDermott, A. B., and F. F. Weight (1982) Action potential repolarization may involve a transient $\mathrm{Ca}^{2+}$-sensitive outward current in a vertebrate neurone. Nature $300: 185-188$.

MacDermott, A. B., and G. L. Westbrook (1986) Early development of voltage-dependent sodium currents in cultured mouse spinal cord neurons. Dev. Biol. 113: 317-326.

Marty, A., and E. Neher (1983) Tight seal whole-cell recording. In Single Channel Recording, B. Sakmann and E. Neher, eds., pp. 107122, Plenum Press, New York.

Matsuda, Y., S. Yoshida, and T. Yonezawa (1978) Tetrodotoxin sensitivity and $\mathrm{Ca}$ component of action potentials of mouse dorsal root ganglion cells cultured in vitro. Brain Res. 154: 69-82.

Meech, R. W. (1974) The sensitivity of Helix aspersa neurones to injected calcium ions. J. Physiol. (Lond.) 237: 259-277.

Meiri, H., M. E. Spira, and I. Parnas (1981) Membrane conductance and action potential of a regenerating axonal tip. Science $211: 709-$ 712.

Miyake, M. (1978) The development of action potential mechanism in a mouse neuronal cell line in vitro. Brain Res. 143: 349-354.

Mori-Okamoto, J., H. Ashida, E. Maru, and J. Tatsuno (1983) The development of action potentials in cultures of explanted cortical neurons from chick embryos. Dev. Biol. 97: 408-416.

Neher, E. (1971) Two fast transient current components during voltage clamp on snail neurons. J. Gen. Physiol. 58: 36-53.

Nerbonne, J. M., A. M. Gurney, and H. B. Rayburn (1986) Development of the fast, transient outward $\mathrm{K}^{+}$current in embryonic sympathetic neurones. Brain Res. 378: 197-202.

Nieuwkoop, P. D., and J. Faber (1956) Normal Table of Xenopus laevis (Daudin). North-Holland, Amsterdam.

O'Dowd, D. K. (1983a) RNA synthesis dependence of action potential development in spinal cord neurones. Nature 303: 619-621.

O'Dowd, D. K. (1983b) Development of voltage-dependent conductances in cultured amphibian spinal neurons. Soc. Neurosci. Abstr. 9: 506.

O'Dowd, D. K. (1985) Changes in membrane conductances that underlie the development of sodium-dependent action potentials in Xenopus spinal neurons. Doctoral dissertation, University of California, San Diego.

Ribera, A. B., and N. C. Spitzer (1987a) Both barium and calcium activate neuronal potassium currents. Proc. Natl. Acad. Sci. USA 84 . $6577-6581$.

Ribera, A. B., and N. C. Spitzer (1987b) Messenger RNA synthesis dependence of potassium currents and a critical period for maturation of the action potential. Soc. Neurosci. Abstr. 13: 177.
Ribera, A. B., D. K. O'Dowd, and N. C. Spitzer (1986) Maturation of outward currents in amphibian spinal neurons developing in culture. Soc. Neurosci. Abstr. 12: 951 .

Sakaguchi, D. S. (1986) Development of voltage-dependent ionic conductances in cultured retinal neurons from Xenopus embryos. Soc. Neurosci. Abstr. 12: 44.

Salkoff, L. B., and R. J. Wyman (1983) Ion currents in Drosophila flight muscle. J. Physiol. (Lond.) 337: 687-709.

Siegelbaum, S. A., and R. W. Tsien (1980) Calcium-activated transient outward current in calf purkinje fibres. J. Physiol. (Lond.) 299: 485506.

Sperelakis, N., and K. Shigenobu (1972) Changes in membrane properties of chick embryonic hearts during development. J. Gen. Physiol. 60: 430-453.

Spitzer, N. C. (1976) The ionic basis of the resting potential and a slow depolarizing response in Rohon-Beard neurones of Xenopus tadpoles. J. Physiol. (Lond.) 255: 105-135.

Spitzer, N. C. (1983) The development of neuronal membrane properties in vivo and in culture. In Developing and Regenerating Vertebrate Nervous Systems, P. Coates et al., eds., pp. 41-59, Alan R. Liss, New York.

Spitzer, N. C., and P. I. Baccaglini (1976) Development of the action potential in embryonic amphibian neurons in vivo. Brain Res. 107: 610-616.

Spitzer, N. C., and J. E. Lamborghini (1976) The development of the action potential mechanism of amphibian neurons isolated in cell culture. Proc. Natl. Acad. Sci. USA 73: 1641-1645.

Standen, N. B. (1975) Voltage-clamp studies of the calcium inward current in an identified snail neurone: Comparison with the sodium inward current. J. Physiol. (Lond.) 249: 253-268.

Stimers, J. R., and L. Byerly (1982) Slowing of sodium current inactivation by Ruthenium Red in snail neurons. J. Gen. Physiol. 80: 485-497.

Storm, J. F. (1987) Action potential repolarization and a fast afterhyperpolarization in rat hippocampal pyramidal slices. J. Physiol. (Lond.) 385: 733-759.

Takahashi, K., S. Miyazaki, and Y. Kidokoro (1971) Development of excitability in embryonic muscle cell membranes in certain tunicates. Science 171:415-417.

Thompson, S. H. (1977) Three pharmacologically distinct potassium channels in molluscan neurones. J. Physiol. (Lond.) 265: 465-488.

Westbrook, G. L., and D. E. Brenneman (1984) The development of spontaneous electrical activity in spinal cord cultures. In Developmental Neuroscience: Physiological, Pharmacological and Clinical Aspects, F. Caciagli, E. Giacobini, and R. Paoletti, eds., pp. 11-17, Elsevier, Amsterdam.

Willard, A. L. (1980) Electrical excitability of outgrowing neurites of embryonic neurones in cultures of dissociated neural plate of Xenopus laevis. J. Physiol. (Lond.) 301: 115-128.

Zbicz, K. L., and F. F. Weight (1985) Transient voltage and calciumdependent outward currents in hippocampal CA3 pyramidal neurons. J. Neurophysiol. 53: 1038-1058. 